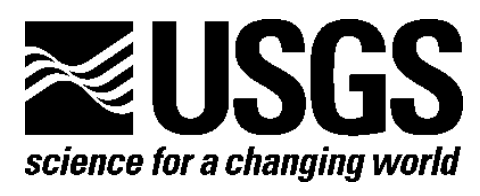

\title{
Identification of Tsunami Deposits in the Geologic Record: Developing Criteria Using Recent Tsunami Deposits
}

Robert Peters and Bruce Jaffe

Open-File Report 2010-1239

U.S. Department of the Interior

U.S. Geological Survey 


\section{U.S. Department of the Interior \\ KEN SALAZAR, Secretary}

\section{U.S. Geological Survey \\ Marcia K. McNutt, Director}

U.S. Geological Survey, Reston, Virginia 2010

For product and ordering information:

World Wide Web: http://www.usgs.gov/pubprod

Telephone: 1-888-ASK-USGS

For more information on the USGS-the Federal source for science about the Earth, its natural and living resources, natural hazards, and the environment:

World Wide Web: http://www.usgs.gov

Telephone: 1-888-ASK-USGS

Suggested citation:

Peters, Robert, and Jaffe, Bruce E., 2010, Identification of tsunami deposits in the geologic record; developing criteria using recent tsunami deposits: U.S. Geological Survey Open-File Report 2010-1239, 39 p.

[http://pubs.usgs.gov/of/2010/1239/.

Any use of trade, product, or firm names is for descriptive purposes only and does not imply endorsement by the U.S. Government.

Although this report is in the public domain, permission must be secured from the individual copyright owners to reproduce any copyrighted material contained within this report. 


\section{Contents}

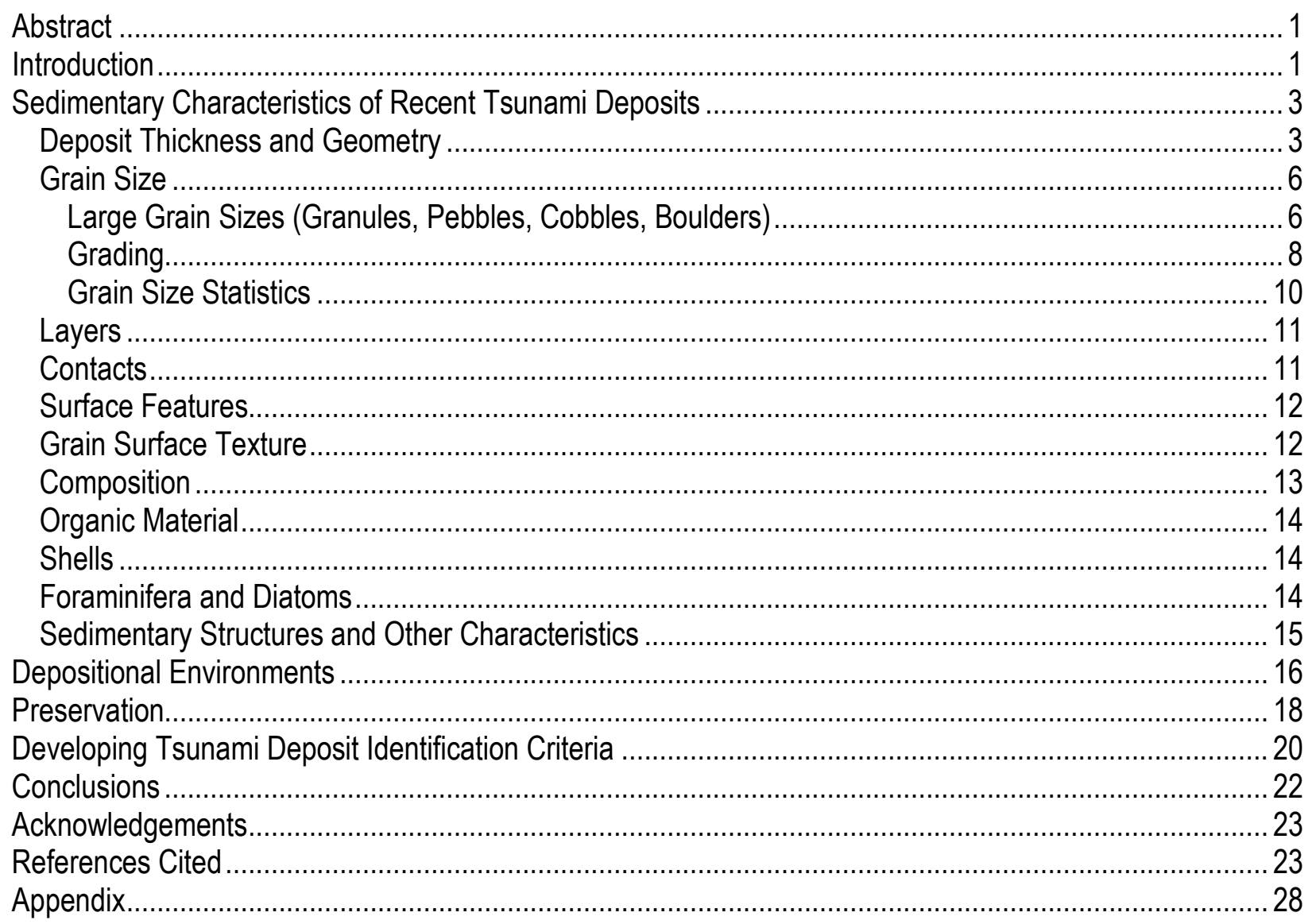

\section{Figures}

Figure 1. World map showing the locations of recent tsunami deposits used in this study and in the Recent Tsunami Deposit Database.

Figure 2. Topographic profile, tsunami deposit thickness, and tsunami flow depths and elevations at Jantang, Sumatra, Indonesia, following the December 26, 2004 tsunami ........................................ 4

Figure 3. Photos of recent tsunami deposits showing deposit characteristics ..................................... 6

Figure 4. La Quinta, Peru; June 23, 2001 tsunami................................................................. 8

Figure 5. Basalt boulder transported by the December 29, 2010 tsunami in Samoa. Photograph

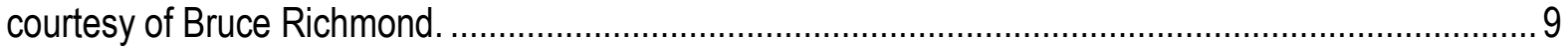

Figure 6. La Quinta, Peru; June 23, 2001 tsunami ........................................................................... 10

Figure 7. Mud cracks at surface of tsunami deposit at Kuala Meurisi, Sumatra, Indonesia. December 26, 2004 tsunami.

Figure 8. A marsh at Lhok Kruet, Sumatra, Indonesia, coseismically subsided and submerged by the December 26, 2004 earthquake and inundated by the tsunami. 
Conversion Factors

Inch/Pound to SI

\begin{tabular}{|c|c|c|}
\hline Multiply & By & To obtain \\
\hline \multicolumn{3}{|c|}{ Length } \\
\hline inch (in.) & 2.54 & centimeter $(\mathrm{cm})$ \\
\hline inch (in.) & 25.4 & millimeter (mm) \\
\hline foot (ft) & 0.3048 & meter (m) \\
\hline mile (mi) & 1.609 & kilometer (km) \\
\hline yard (yd) & 0.9144 & meter $(\mathrm{m})$ \\
\hline \multicolumn{3}{|c|}{ Mass } \\
\hline ounce, avoirdupois (oz) & 28.35 & $\operatorname{gram}(\mathrm{g})$ \\
\hline pound, avoirdupois (lb) & 0.4536 & kilogram (kg) \\
\hline ton, short $(2,000 \mathrm{lb})$ & 0.9072 & megagram (Mg) \\
\hline ton, long $(2,240 \mathrm{lb})$ & 1.016 & megagram (Mg) \\
\hline \multicolumn{3}{|l|}{ SI to Inch/Pound } \\
\hline Multiply & By & To obtain \\
\hline \multicolumn{3}{|c|}{ Length } \\
\hline centimeter $(\mathrm{cm})$ & 0.3937 & inch (in.) \\
\hline millimeter (mm) & 0.03937 & inch (in.) \\
\hline meter (m) & 3.281 & foot (ft) \\
\hline kilometer (km) & 0.6214 & mile (mi) \\
\hline meter $(\mathrm{m})$ & 1.094 & yard (yd) \\
\hline \multicolumn{3}{|c|}{ Mass } \\
\hline $\operatorname{gram}(\mathrm{g})$ & 0.03527 & ounce, avoirdupois (oz) \\
\hline kilogram (kg) & 2.205 & pound avoirdupois (lb) \\
\hline megagram (Mg) & 1.102 & ton, short $(2,000 \mathrm{lb})$ \\
\hline megagram (Mg) & 0.9842 & ton, long $(2,240 \mathrm{lb})$ \\
\hline
\end{tabular}




\title{
Identification of Tsunami Deposits in the Geologic Record: Developing Criteria Using Recent Tsunami Deposits
}

\author{
Robert Peters and Bruce Jaffe
}

\begin{abstract}
There is a need for a clear procedure to identify tsunami deposits in the geologic record. Data from published studies documenting recent tsunami deposits provide a means of developing identification criteria based on the sedimentary characteristics of unequivocal tsunami deposits. Recent tsunami deposits have many sedimentary characteristics in common. All had sharp or erosional basal contacts. Sand was typically deposited in sheets that blanketed pre-existing topography and generally thinned landward. Deposit thickness was dependent on local topography; deposits were thicker in swales or local depressions and thinner on ridges or topographic highs. Deposits typically had 1-4 layers. Normal grading was common and often confined to individual layers. In muddy environments, sediments contained mud and soil rip-up clasts and mud often capped the deposits or layers. Boulders were often present, either isolated or scattered in groups. Sedimentary structures were rare, and included cross-bedding, laminations, scour and fill structures, and truncated flame structures. The composition, grain size, and surface texture of the grains reflected the coastal and nearshore source for the sediments. These sedimentary characteristics are the basis for developing site-specific tsunami deposit identification criteria that can be used in paleotsunami deposits investigations.
\end{abstract}

\section{Introduction}

Recent tsunamis, including the February 27, 2010 Chile tsunami (Morton and others, 2010), the September 29, 2009, Samoa-Tonga tsunami (Lay and others, 2010) and the December 12, 2004, Indian Ocean tsunami (Lay and others, 2005; Titov and others, 2005), have emphasized the need to assess tsunami hazards worldwide to help mitigate the impacts, including loss of life and property and damage to cities, communities and infrastructure, that these events can bring. Over the last two decades, tsunami deposit investigations have become a key component in efforts to evaluate tsunami risk to communities.

Tsunami deposits are often used in the evaluation of tsunami hazard. Tsunami hazard maps use tsunami deposits to validate and to expand on the results of tsunami inundation modeling (Priest and others, 1997; Walsh and others, 2000). A probabilistic tsunami hazard assessment used tsunami deposit evidence from the 1964 Alaska and the 1700 Cascadia tsunamis in combination with modeling results to include tsunami inundation in modernizing Federal Emergency Management Agency (FEMA) flood hazard maps for portions of the Oregon coast (Tsunami Pilot Study Working Group, 2006; Gonzalez and others, 2009). To evaluate potential sites for future nuclear power plants, the Nuclear Regulatory Commission requires tsunami deposit studies (Moore and Jaffe, 2007). Tsunami deposit studies are important in evaluating the safety of other potentially hazardous coastal installations, such as liquid natural gas facilities (Ross and others, 2004).

There is a need for clear methods to identify tsunami deposits in the geologic record. Tsunami deposit identification criteria have been derived from a number of sources, each criterion with their 
benefits and limitations. Criteria have been established based on sedimentary characteristics of paleotsunami deposits (Dawson and Shi, 2000; Schlichting and Peterson, 2006). The benefit of this approach is that it uses tsunami deposits as they appear in the geologic record and as they are seen in paleotsunami deposit studies. A problem with this approach is that the identifying sedimentary characteristics are based on interpreted rather than known tsunami deposits. Another problem is that only a limited portion of the tsunami deposit can be seen in the cores, cutbanks, and trenches used to evaluate the deposits. Tsunami deposit characteristics have also been derived from inverse modeling of tsunami depositional processes (Jaffe and Gelfenbaum, 2007; Moore and others, 2007; Soulsby and others, 2007). The benefit is that tsunami depositional processes are taken into account in establishing deposit characteristics. However, modeling studies usually rely on a set of idealized or simplified parameters or assumptions that may neglect the complications of an actual tsunami deposit (Jaffe and Gelfenbaum, 2007; Moore and others, 2007; Soulsby and others, 2007). Several studies address the specific issue of distinguishing tsunami deposits from storm deposits (Nanayama and others, 2000; Goff and others, 2004; Tuttle and others, 2004; Kortekaas and Dawson, 2007; Morton and others, 2007); these studies are limited to only one aspect of the problem and need to be used in conjunction with other tsunami deposit identification studies. Many previous studies have recognized the need to base the identifying criteria for tsunami deposits in the geologic record on modern tsunami deposits (Nanayama and others, 2000; Kortekaas and Dawson, 2007; Morton and others, 2007). These previous studies are limited to specific regions and tsunamis.

Peters and Jaffe (2010) compiled a database of the results of studies documenting the sedimentary characteristics of recent tsunami deposits for use in evaluating tsunami deposit characteristics. The database includes data from 51 publications documenting tsunami deposits from 15 recent tsunamis (fig. 1, Appendix 1). We use data from these studies to derive a set of tsunami deposit characteristics and identification criteria based on recent tsunami deposits.

Limitations to the approach presented here are that sedimentary characteristics based on modern unequivocal tsunami deposits provide no data on how tsunami deposits look where they are preserved in the geologic record. More needs to be learned about how tsunami deposits change over time and recent tsunami deposits provide a perfect opportunity to study tsunami deposit preservation and alteration, at least in the short term. Only one study included in the database addresses these issues (Nichol and Kench, 2008). In this study we discuss limitations of the approach including which environments are most likely to preserve tsunami deposits (not necessarily those studied), which characteristics are the likeliest to be preserved, and which characteristics are most likely to be altered or destroyed by postdepositional processes.

We conclude by presenting an approach for identifying tsunami deposits in the geologic record based on sedimentary characteristics of recent tsunami deposits. This approach emphasizes the development of site-specific identification criteria that take into account tsunami depositional processes, depositional environments, surrounding environments, and sediment sources, in conjunction with known historic or prehistoric tsunami occurrence, geologic evidence for tsunami potential, and modeling studies. The identification criteria presented here are a valuable tool for use in determining a tsunami origin for a deposit. 


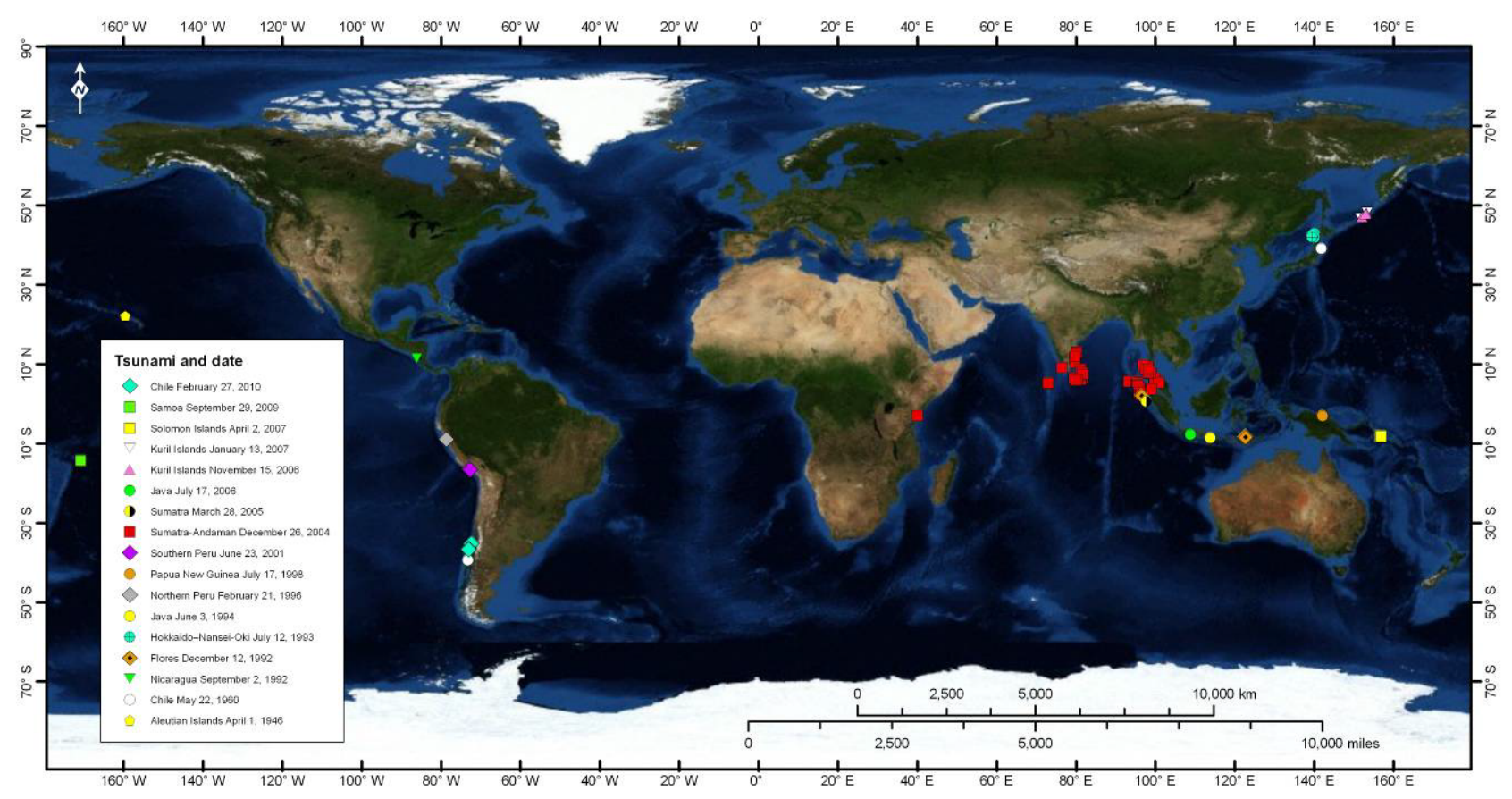

Figure 1. World map showing the locations of recent tsunami deposits used in this study and in the Recent Tsunami Deposit Database. The points represent the exact, representative, or estimated locations of study sites. These points do not clearly indicate the lateral extent of the tsunami deposits, which in many cases covered large portions of the coastline.

\section{Sedimentary Characteristics of Recent Tsunami Deposits}

Studies of recent tsunami deposits document a great variety of sedimentary characteristics of tsunami deposits. The variety of sedimentary characteristics makes generalizations about what characterizes a tsunami deposit difficult. It is important to note what is a common or defining characteristic, what sedimentary characteristics are possible but rare, and what characteristics are inconsistent with tsunami deposition.

\section{Deposit Thickness and Geometry}

Investigations of recent tsunami deposits recorded sediment thicknesses ranging from a thin veneer of sand to deposits up to $150 \mathrm{~cm}$ thick (Peters and Jaffe, 2010). Deposits were commonly less than $20 \mathrm{~cm}$ thick and rarely exceeded a few tens of centimeters. Thicker accumulations of sediment tended to be localized. Most tsunami deposits investigated are in the form of continuous sand sheets. Lobe-shaped deposits occur in several localities (Nanayama and Shigeno, 2006; Kench and others, 2007; Matsumoto and others, 2008; Nichol and Kench, 2008). Where sedimentation is minimal, deposits may only occur as thin patches filling depressions (Razzhigaeva and others, 2006). Where the deposit consists of larger grain sizes, such as cobbles or boulders, the deposits may be scattered or patchy (Hawkes and others, 2007; Higman and Bourgeois, 2008; MacInnes and others, 2009a; Paris and others, 2009; Yawsangratt and others, 2009).

Tsunami deposits generally thicken over a short distance after a zone of erosion that may extend up to several tens of meters inland from the shore, then thin landward, extending to near the limit of inundation, where the deposits may become discontinuous and patchy. In some cases, a clear landward 
thinning of the deposits was not obvious, particularly if the deposits were thin near the coast or if thickness was controlled mainly by local topography (Hori and others, 2007). Deposit thickness may be relatively constant throughout most of the depositional zone with abrupt thinning at the distal end (Richmond and others, 2006). Local discontinuity around obstructions, such as tree trunks, has been reported (Morton and others, 2008), as has thickening in front (seaward) of obstructions such as walls (Razzhigaeva and others, 2006). In many cases, thickness is variable and typically follows local topography; deposits thin over local highs and are thicker where deposits fill local depressions. Topographically controlled variations in sediment thickness were common where variations in topography were large, such as in ridge-and-swale topography (Jaffe and others, 2006) (fig. 2). Variability in thickness was also observed on a much smaller scale. In places where tsunamis inundated agricultural fields, deposits were thickest on the lee side or bottom of the furrows and thinned along the furrow crests (Bourgeois and others, 1999; Jaffe and others, 2003; Morton and others, 2007).

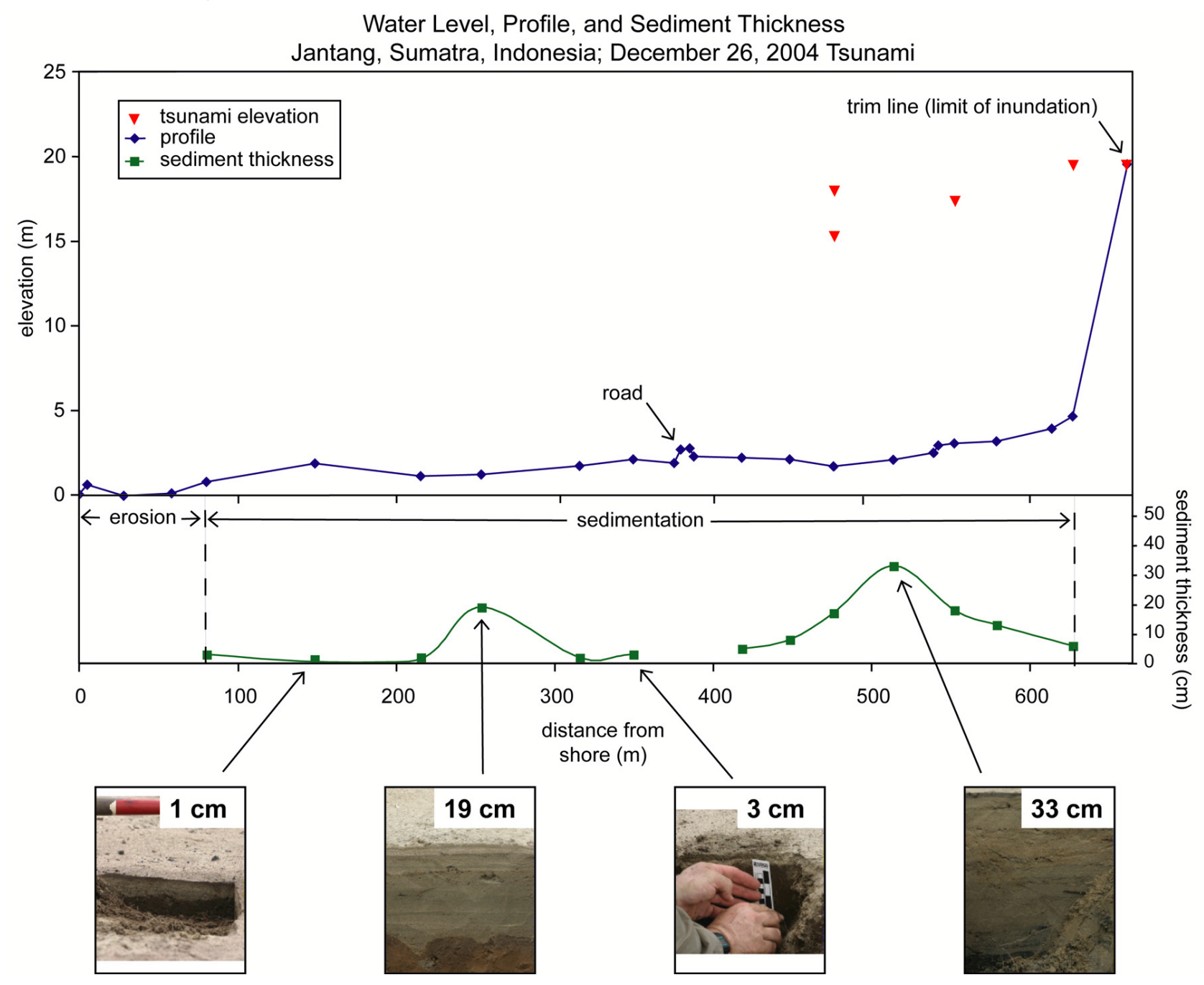

Figure 2. Topographic profile, tsunami deposit thickness, and tsunami flow depths and elevations at Jantang, Sumatra, Indonesia, following the December 26, 2004 tsunami. Photographs of the tsunami deposit are from trenches at $149 \mathrm{~m}, 254 \mathrm{~m}, 350 \mathrm{~m}$, and $514 \mathrm{~m}$. Tsunami deposit thickness varied along the transect, responding to topographic changes, and there was a zone of erosion seaward of the tsunami deposit. 

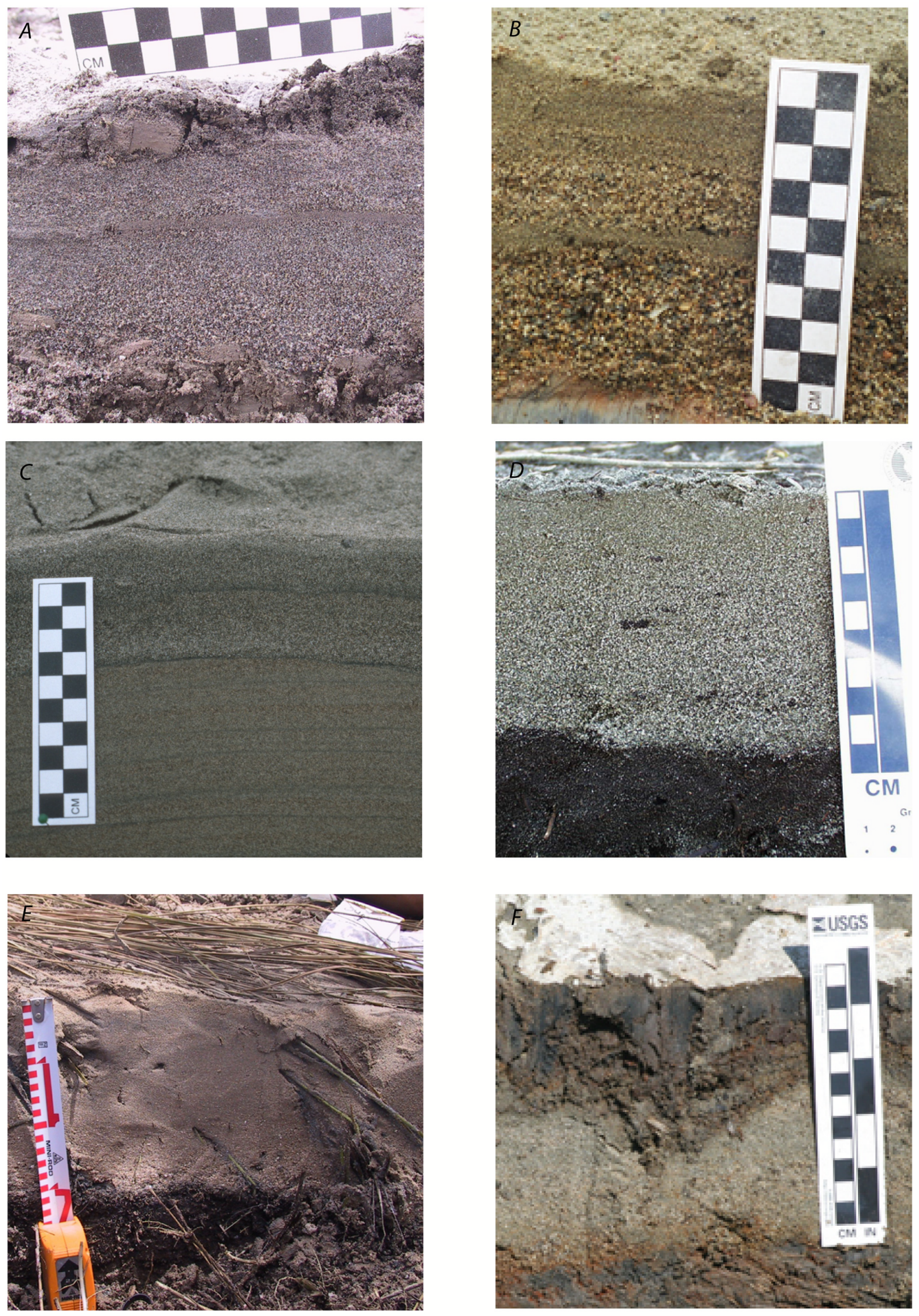
Figure 3. Photos of recent tsunami deposits showing deposit characteristics. A, La Quinta, Peru; June 23, 2001 tsunami. Mud surface cap, mud rip-up clasts, thin mud layer separating two sand layers, normal grading in each sand layer, sharp basal contact. Tsunami deposit overlies muddy soil. Photograph courtesy of David Rubin. B, Jantang, Sumatra, Indonesia; December 26, 2004 tsunami. Two layers separated by a thin layer of fine sand. Upper layer is normally graded, lower layer composed of coarse sand and shell fragments. Tsunami deposit overlies mud. C, Playa Jahuay, Peru; June 23, 2001 tsunami. Two normally graded layers separated by a dark heavy mineral layer, erosional basal contact. Tsunami deposit overlies fluvial sand. D, Papua New Guinea; July 17, 1998 tsunami. Single layer of normally graded sand with small soil rip-up clasts. Tsunami deposit overlies soil. E, La Gundri Bay, Nias, Indonesia; March 28, 2005 tsunami. Single layer deposit with bent vegetation in deposit and at surface, rooted at base, sharp basal contact. Tsunami deposit overlies soil. F, Kuala Meurisi, Sumatra, Indonesia; December 26, 2004 tsunami. Mud cap 2-5 cm thick, irregular erosional base. Tsunami deposit overlies mud. Scale bars are in centimeters.

\section{Grain Size}

The grain sizes found in recent tsunami deposits ranged from clay to boulders and were largely a function of what material was available to transport. The sand fraction is most commonly noted in studies of recent tsunami deposits and in many cases makes up the largest part of the tsunami deposit. Silt and clay are usually present to some degree in sandy tsunami deposits, but also may be deposited separately from the sand, forming a distinctive unit between layers and sometimes form a surface cap (fig. $3 \mathrm{~A}$ ). Mud may be the only material present at the distal end of the tsunami deposit (Higman and Bourgeois, 2008).

\section{Large Grain Sizes (Granules, Pebbles, Cobbles, Boulders)}

Large grain sizes were found at many recent tsunami deposit sites. Pebbles were a common component of many tsunami deposits. Cobble-sized clasts were also found in several deposits (Sato and others, 1995; Jaffe and others, 2003; Higman and Bourgeois, 2008; MacInnes and others, 2009a,b; Morton and others, 2010). At La Quinta, Peru, cobbles from the June 21, 2001, tsunami were scattered both at the surface and within the deposit (Jaffe and others, 2003) (fig. 4A). The source of the cobbles was a cobble berm at the shoreline. Tsunami-deposited cobbles directly behind the berm formed a continuous narrow band and were imbricated, showing landward transport (fig. $4 B$ ).

The transport and deposition of boulders was documented at several sites. Shepard and others (1950) observed rocks and coral boulders up to 12 feet (3.7 meters) wide in Hawaii, USA, following the April 1, 1946, tsunami. Higman and Bourgeois (2008) describe boulders composed of large blocks of beachrock in deposits from the September 2, 1992, tsunami in Nicaragua. Shi and others (1995) found that in deposits from the December 12, 1992, tsunami at Riagkrok, Flores Island, Indonesia, where the tsunami runup was in excess of $26 \mathrm{~m}$, deposition of coral boulders was widespread. In other places on Flores Island where runup was considerably less $(2-5 \mathrm{~m})$, sediments were largely composed of sand. On Babi Island, a small circular island $5 \mathrm{~km}$ off of the coast of Flores Island, where maximum runup was 5.6 meters, coral boulders were also deposited by the December 12, 1992, tsunami (Minoura and others, 1997). Morton and others (2007) note boulder deposition for the June 23, 2001, tsunami in southern Peru. Boulder deposition was widely documented from the December 12, 2004, tsunami. At Lhok Nga, Sumatra, Indonesia, where wave heights were up to $30 \mathrm{~m}$ and runup up to $51 \mathrm{~m}$, Paris and others (2009) described boulders deposited by the tsunami. Typically meter-scale, the boulders ranged in size from 0.3 $\mathrm{m}$ to $7.2 \mathrm{~m}$. The boulders were composed of coral, beachrock, and limestone. Razzhigaeva and others (2006) reported large blocks of reef transported landward $400 \mathrm{~m}$. at Langi on Simeulue Island off of the coast of Sumatra, Indonesia. Goto and others (2009) documented thousands of meter-scale boulders composed of coral reef material at Pakarang Cape, Thailand. Kelletat and others (2007) describe 

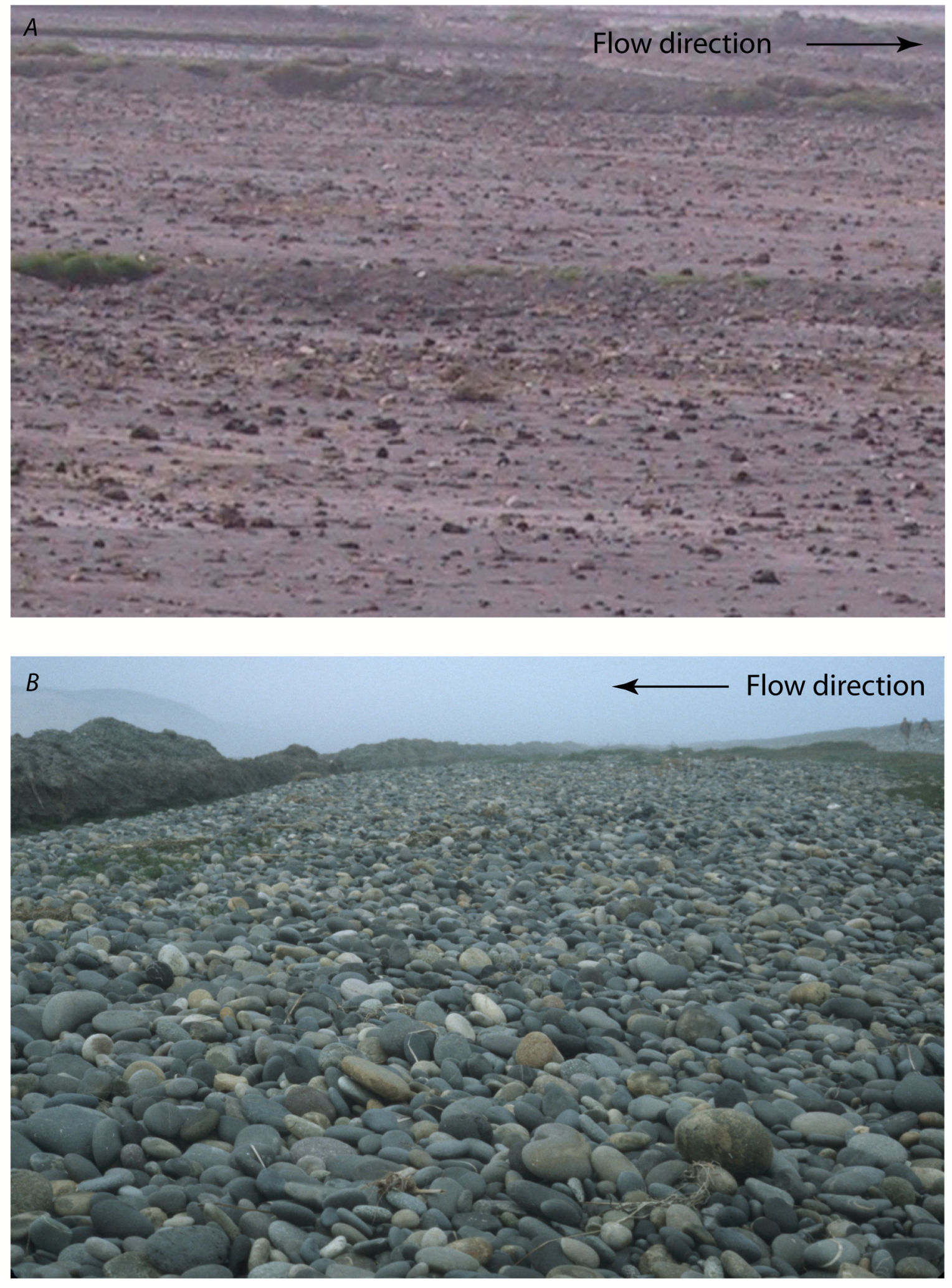
Figure 4. La Quinta, Peru; June 23, 2001 tsunami. A, Cobbles and coherent blocks of mud were scattered on the surface of the tsunami deposit. The tsunami deposit overlies an agricultural field. A thin mud cap covered much of the surface of the tsunami deposit. Photograph courtesy of Roberto Anima. B, Cobbles deposited near the shore were imbricated by the tsunami uprush. Shortly after the tsunami, normal coastal processes formed a cobble berm at the beach. The beach was composed primarily of cobbles.

boulders deposited by the tsunami. Typically meter-scale, the boulders ranged in size from $0.3 \mathrm{~m}$ to 7.2 $\mathrm{m}$. The boulders were composed of coral, beachrock, and limestone. Razzhigaeva and others (2006) reported large blocks of reef transported landward $400 \mathrm{~m}$. at Langi on Simeulue Island off of the coast of Sumatra, Indonesia. Goto and others (2009) documented thousands of meter-scale boulders composed of coral reef material at Pakarang Cape, Thailand. Kelletat and others (2007) describe boulders from locations near Phuket, Thailand, weighing up to 40 tons, including two granite boulders dislocated up to 5 meters. Transport distances may have been significantly greater because the source of boulders was several hundred meters offshore. Yawsangratt and others (2009) describe 18 granite boulders from Phang Nga Province, Thailand. The average weight was 2.14 tons and maximum weight was 6.32 tons. The boulders were scattered on a flat plain between 30 and $140 \mathrm{~m}$ from shoreline with almost half lined up in a row about $80 \mathrm{~m}$ from the coastline. Fresh, unweathered surfaces and rims of oyster shells indicated origin at modern coastline. In Sri Lanka, Goff and others (2006) also observed boulders deposited by the tsunami. In the Maldives, Kench and others (2007) document boulders of beachrock up to 2 meters long transported 3 meters. Narayana and others (2007) report boulder deposition along the Kerala coast of southwest India. Boulders deposited by the April 2, 2007, tsunami in the Solomon Islands originated from both the modern reef and backing hillside (McAdoo and others, 2008). Boulders up to 3 meters were reported from the Kuril Islands, Kamchatka, Russia (MacInnes and others, 2009a,b). Sites with boulder deposition were described as bouldery pocket beaches. Two tsunamis occurred at this location within two months of each other (November 15, 2006 and January 13, 2007). The boulders described were most likely deposited by the larger tsunami of November 15, 2006. Mud boulders were observed in Chile from the February 27, 2010, tsunami (Morton and others, 2010). Basalt boulders transported by the September 29, 2009, tsunami were documented in Samoa (DominyHowes and Thaman, 2009) and in American Samoa (Jaffe and others, 2010), (fig. 5).

\section{Grading}

At recent tsunami sites, grading was observed both laterally and vertically. Recent tsunami deposits generally show a landward-fining trend (Higman and Bourgeois, 2008; Morton and others, 2008; Jagodziski and others, 2009; MacInnes and others, 2009b), although this characteristic was not universal. At the seaward edge, a narrow landward-coarsening band is common. Local landward coarsening of the deposits was also observed (Razzhigaeva and others, 2006; Higman and Bourgeois, 2008; Morton and others, 2008; Srinivasalu and others, 2009). A landward coarsening trend, usually restricted to the first 10-15 meters of the deposit, was observed on several islands in the Maldives following the 2004 Indian Ocean tsunami (Kench and others, 2007). At Yala, Sri Lanka, cross-shore grading trends were dependent on landward distance and depth within the deposit (Morton and others, 2008). 


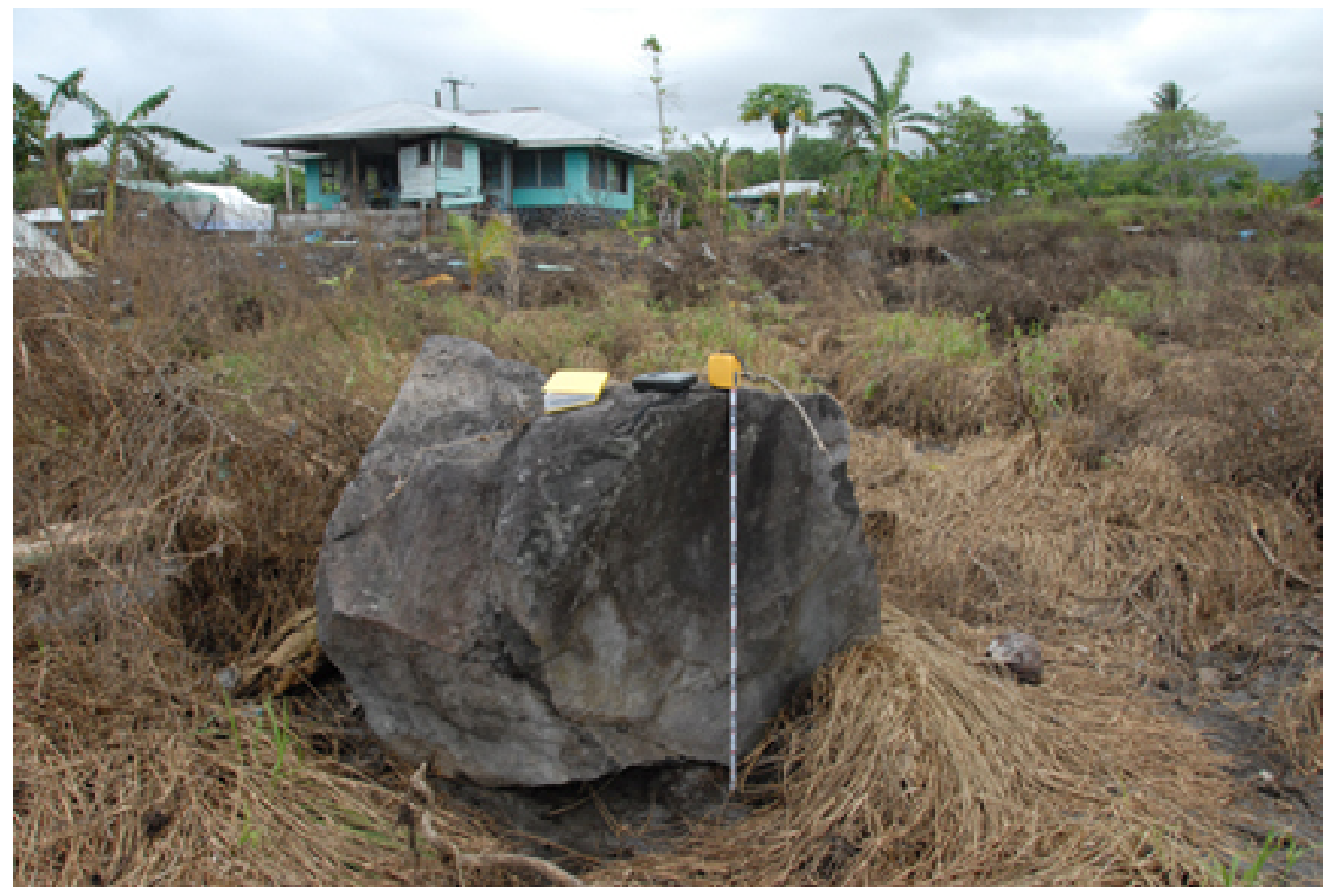

Figure 5. Basalt boulder transported by the December 29, 2010 tsunami in Samoa. Photograph courtesy of Bruce Richmond.

Normal grading was common in tsunami deposits. A tsunami deposit may consist of one normally graded layer (see Gelfenbaum and Jaffe, 2003) or consist of multiple layers, with one or more layers normally graded (Minoura and others, 1997; Gelfenbaum and Jaffe, 2003; Jaffe and others, 2003; Jaffe and others, 2006; Razzhigaeva and others, 2006; Hawkes and others, 2007; Hori and others, 2007; Morton and others, 2007; Choowong and others 2008; Jackson, 2008; Srinivasalu and others, 2009) (fig. $3 A, B, C$; fig. 6). In some cases, only the upper portion of a layer was normally graded. Massive (ungraded) tsunami deposits were also common (Razzhigaeva and others, 2006; Richmond and others, 2006; Morton and others, 2007; Jackson, 2008; Srinivasalu and others, 2009) (fig. 3E). Massive or normally graded sections may only be locally present (Hori and others, 2007; Morton and others, 2007, Srinivasalu and others, 2009). In some cases, inverse grading was observed at the base of the deposit (Higman and Bourgeois, 2008) or within the deposit (Jaffe and others, 2006; Nanayama and Shigeno, 2006; Richmond and others, 2006; Morton and others, 2007; Jackson, 2008; Morton and others, 2008). 


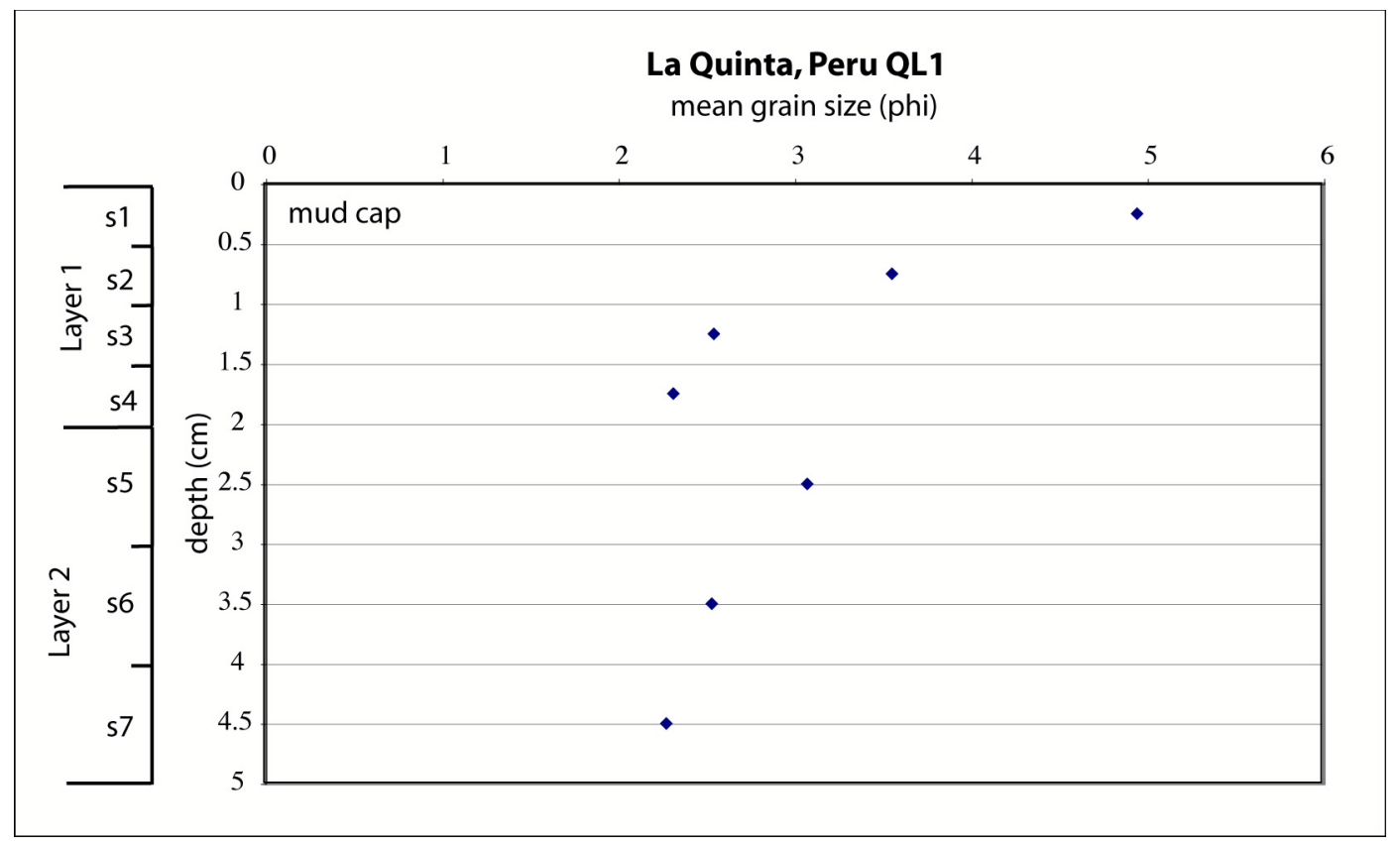

Figure 6. La Quinta, Peru; June 23, 2001 tsunami. Mean grain size for sample intervals s1 - s7 from hole $\mathrm{QL1}, 121.4 \mathrm{~m}$ inland from the shoreline. The tsunami deposit consists of two normally graded layers. Layer $\mathrm{s} 1$ represents a surface mud cap.

\section{Grain Size Statistics}

Statistical results calculated from grain size analyses were reported for several of the recent tsunami deposit sites investigated. The grain size statistics reported include mean, median, mode, standard deviation (sorting), skewness, and kurtosis. While numerical statistical results of grain size analyses were reported in several investigations (Nishimura and Miyaji, 1995; Nanayama and others, 2000; Gelfenbaum and Jaffe, 2003; Szczucinski and others, 2005; Razzhigaeva and others, 2006; Narayana and others, 2007; Nichol and Kench, 2008), more often, non-numerical interpretations were provided. It is difficult to compare statistics from different studies because there is not a uniform protocol for sampling tsunami deposits and whole data sets are not included. Therefore, no attempt is made here to develop a statistical approach for developing tsunami deposit identification criteria based on these studies. The reader is referred to individual studies to evaluate sampling protocol and compare results between studies.

There is no characteristic value of mean, median or mode that can be used to determine a tsunami origin because the range of grain sizes in a tsunami deposit is largely controlled by the sediment source. These statistics may help determine a sediment source, but sorting processes during transport and deposition may alter the distributions (Shi and others, 1995). Vertical and lateral changes in the mean and median are useful in determining grading. Nanayama and Shigeno (2006) found that a bimodal distribution in deposits from the 1993 Hokkaido tsunami indicated a marine sediment source and a terrestrial source.

The standard deviation of the grain size distribution provides a numerical measure of sorting the smaller the standard deviation, the greater the sorting of the grain sizes in the deposit. Sorting in recent tsunami deposits ranged from very poorly sorted to very well sorted. Vertical and lateral trends in sorting were sometimes noted but no consistent trends were found. Morton and others (2008) noted both better sorting upwards and poorer sorting upwards in deposits from Yala, Sri Lanka, following the 
December 12, 2004, tsunami. Morton and others (2008) also observed the poorest sorting at the top of a deposit that otherwise exhibited a trend towards better sorting upwards and noted that sorting may vary with layers and within layers. Higman and Bourgeois (2008) observed better sorting at the top of deposits from the 1992 Nicaragua tsunami. Trends to poorer sorting inland were observed (Razzhigaeva and others, 2006; Monecke and others, 2008; Nichol and Kench, 2008), as were trends towards better sorting inland (Razzhigaeva and others, 2006). Trends in sorting are clearly dependent on local conditions and determined by interactions among wave properties, depositional environment, and sediment source.

Skewness is statistic that describes the asymmetry of a frequency distribution. Several authors investigating deposits from the 2004 Indian Ocean tsunami noted the skewness of grain size distributions but no clear trends were found. At Yala, Sri Lanka, Morton and others (2008) observed both finely skewed distributions and distributions that varied between finely and coarsely skewed over a $4 \mathrm{~cm}$ cycle. Skewness varied from strongly coarse to strongly fine in Thailand (Szczucinski and others, 2005; Yawsangratt and others, 2009). Deposits from India and Kenya had distributions that were symmetrical to finely skewed (Bahlburg and Weiss, 2007).

Kurtosis is statistic that describes the peakedness of a frequency distribution. A normal (Gaussian) distribution is mesokurtic, a flattened distribution is platykurtic, and a sharper-peaked distribution is leptokurtic. Kurtosis of grain size distributions from recent tsunami deposits varied widely. While Morton and others (2008) found the grain size distributions from most of the deposits sampled at Yala, Sri Lanka following the 2004 Indian Ocean tsunami to be leptokurtic, distributions ranged from platykurtic to very leptokurtic and kurtosis varied with depth and with unit within the deposit. On Phuket Island, Thailand, Szczucinski and others (2005) found grain size distributions at most sites to be leptokurtic to very leptokurtic, although at one site, the distributions were mesokurtic to platykurtic. At Tamil Nadu, India, distributions were mesokurtic to leptokurtic (Bahlburg and Weiss, 2007). Dawson and others (1996) found that kurtosis and skewness paralleled each other closely but did not correspond with changes in sorting or the mean.

\section{Layers}

Internal layering was commonly observed in recent tsunami deposits. The number of layers present ranged from 1 to 7 (Peters and Jaffe, 2010). Tsunami deposits having one or two layers were most common, while deposits having more than four layers were rare. Layers were usually delineated by changes in the grain size of the deposits. A thin layer of fine sand, silt, clay, or mud sometimes separated the layers (Jaffe and others, 2003; Razzhigaeva and others, 2006) (fig. 3A, B). In this report, the sequence of a layer of sand capped by a thin layer of mud is termed a single layer. A thin layer of dark or heavy minerals sometimes separated layers (Jaffe and others, 2003; Bahlburg and Weiss, 2007; Morton and others, 2007; Jackson, 2008; Srinivasalu and others, 2009) (fig. 3C). Some layers consisted of 2 or more normally graded sequences (for example, Shi and others, 1995; Gelfenbaum and Jaffe, 2003; Morton and others, 2008). The number of layers was not always constant within any one deposit. For example, the number of layers was observed to decrease landward in deposits from the 2001 Peru tsunami (Jaffe and others, 2003; Morton and others, 2007).

\section{Contacts}

Sharp or abrupt basal contacts characterized the deposits. The basal contacts were often erosional, and in some cases were irregular or undulating (fig. $3 A, B, D, E, F$ ). An important incidence of a non-erosional basal contact is where tsunami-deposited sediments overlie a prior vegetated surface (Nishimura and Miyaji, 1995; Gelfenbaum and Jaffe, 2003; Jaffe and others, 2006; Higman and Bourgeois, 2008; Kelletat and others, 2007; MacInnes and others, 2009a,b; Morton and others, 2010) 
(fig. $3 E$ ). Bent vegetation (flop-overs) at this surface may provide indications of flow direction and, in paleotsunami deposits, may provide good material for radiocarbon dating. The field surveys were usually conducted before an overlying deposit had time to develop. Therefore, upper contacts were rarely observed. Where sediment was present overlying the tsunami deposit, the upper contacts were gradational to sharp (Jackson, 2008).

\section{Surface Features}

Recent tsunami deposits are usually found at the surface, providing an ideal opportunity to observe the surface of the deposit. Surface features of tsunami deposits may be preserved in the geologic record. A layer of mud, silt, clay, or other fines often caps the tsunami deposits. Mud cracks may form in this surface layer (Jaffe and others, 2006) (fig. 7). Very coarse material such as cobbles or boulders may be present at the surface, overlying the tsunami-deposited sand (Jaffe and others, 2003; Morton and others, 2007; Higman and Bourgeois, 2008; Paris and others, 2009). Coherent blocks of mud or other underlying material may also be present at the surface (Jaffe and others, 2003; Morton and others, 2007, Morton and other, 2010) (fig. 4A). Shells and shell fragments were present at the surface of some of the tsunami deposits investigated. On Babi Island, following the 1992 Flores tsunami, molluscan shells were present at the surface of the tsunami deposit (Minoura and others, 1997). Shells were present at the surface of most sites investigated on Papua New Guinea following the June 17, 1998, tsunami and whole sand dollars were found up to $500 \mathrm{~m}$ inland (Gelfenbaum and Jaffe, 2003; Morton and others, 2007). In the Maldives, Halimeda flakes and coral fragments were observed at the surface (Kench and others, 2007; Nichol and Kench, 2008). Current ripples may be present, often with their steep side dipping seaward indicating they were formed by return flow (Nishimura and Miyaji, 1995; Sato and others, 1995; Jaffe and others, 2003; Nanayama and Shigeno, 2006; Morton and others, 2007; Choowong and others, 2007; Choowong and others, 2008). Salt encrustation may be present where ponded seawater evaporated (Srinivasalu and others, 2009). In the absence of rapid burial, the surface deposits may be reworked (Hori and others, 2007). In Chile, following the February 27, 2010 , tsunami, portions of the surface of the tsunami deposit was modified by eolian processes (Morton and others, 2010).

\section{Grain Surface Texture}

The angularity of clasts in a tsunami deposit can be useful for determining sediment source. Grain surface texture is unlikely to change during transportation by a tsunami due to the short distances and brief transport time involved. Sediments from surrounding coastal environments that are potential sediment sources may have distinguishing grain surface textures. While seldom reported in recent tsunami deposit studies, this characteristic was noted in two studies. In Thailand, following the Indian Ocean tsunami, angular mineral fragments were identified as having been transported from the beach and foreshore (Kelletat and others, 2007). Rounded cobbles were present within and at the surface of tsunami deposits composed primarily of sand and mud overlying agricultural fields at La Quinta, Peru (fig. $4 A$ ). Rounding of the cobbles took place prior to the tsunami. The source of the rounded cobbles in the tsunami deposit was a cobble beach and berm at the shoreline (Jaffe and others, 2003) (fig. 4B). At this site, neither sand nor mud was present at the beach. The mud was eroded from the agricultural fields inundated by the tsunami and the sand was likely transported from offshore. 


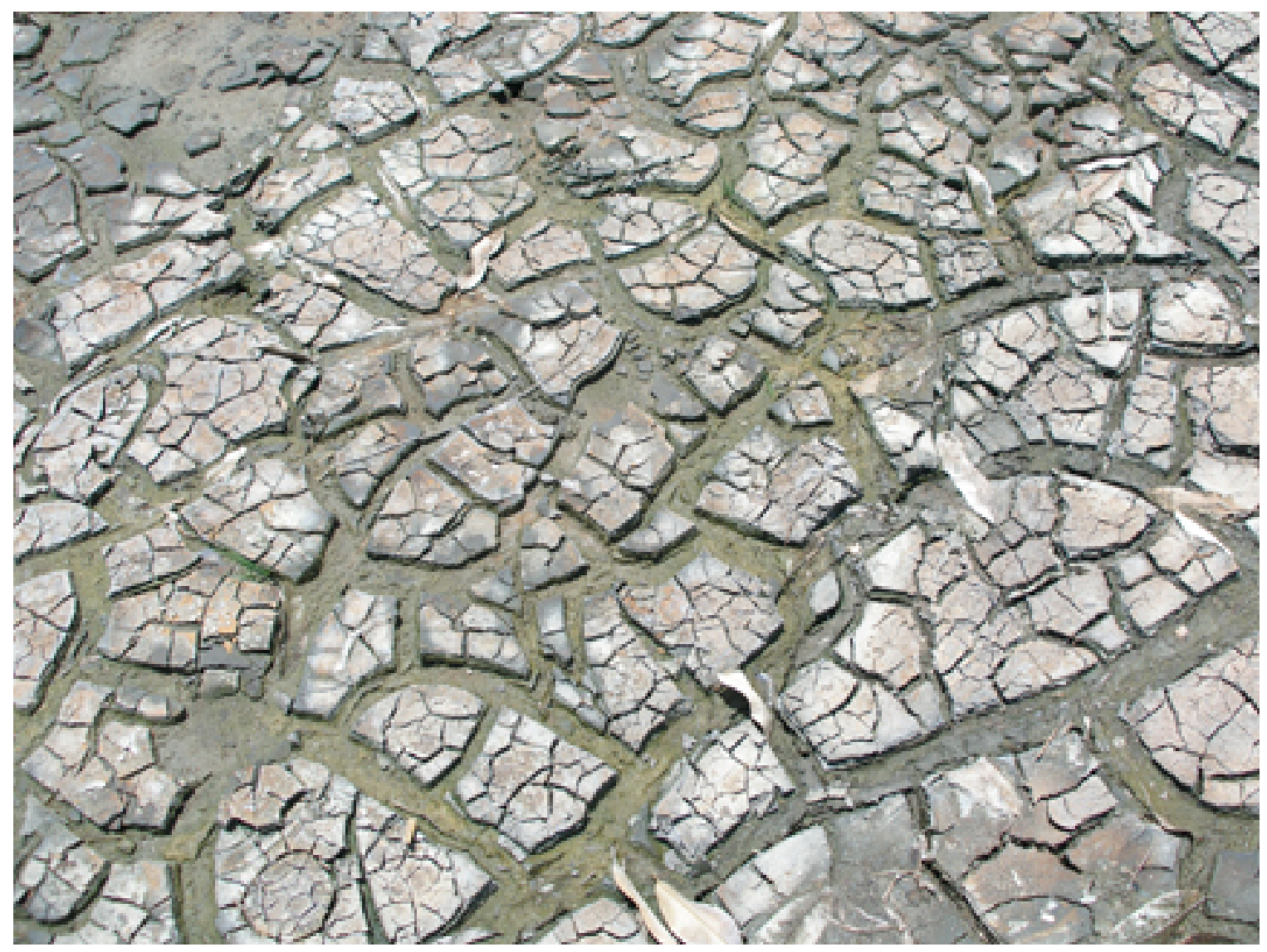

Figure 7. Mud cracks at surface of tsunami deposit at Kuala Meurisi, Sumatra, Indonesia. December 26, 2004 tsunami. Photograph courtesy of Guy Gelfenbaum.

\section{Composition}

The composition of tsunami sediments reflects the local coastal environments from which the sediment is derived (Jaffe and others, 2003; Goff and others, 2006; Morton and others, 2007). At Playa Jahuay, Peru, following the June 21, 2001, tsunami, the mineralogy of the tsunami deposit was similar to the sand found on the nearby beach and contrasted with mineralogy of the underlying fluvial sand (Jaffe and others, 2003) (fig. 3C). Carbonate sand was a common component of tsunami deposits in tropical settings, making up all or part of the deposit. In the Maldives, where the beaches were composed primarily of carbonate sand, so were the tsunami deposits (Nichol and Kench, 2008). Coral reef material was a common component in regions where a reef was present (Minoura and others, 1997; Kelletat and others, 2007; Kench and others, 2007; McAdoo and others, 2008; Nichol and Kench, 2008; Goto and others, 2009). Beach rock was also a component of some deposits in tropical or sub-tropical settings (Higman and Bourgeois, 2008; Kench and others, 2007; Paris and others, 2009). Siliciclastic sand was common in both tropical and non-tropical environments. Razzhigaeva and others (2006) noted that at Sibao, on Simeulue Island, Indonesia, the coarse-grained fractions of the deposit were composed of carbonate material, and the fine-grained fractions consisted largely of terrigenous particles dominated by quartz. Minerals commonly found in non-carbonate beach sand, such as quartz and feldspar make up a significant part of siliciclastic tsunami deposits (Razzhigaeva and others, 2006; Kelletat and others, 2007; Jackson, 2008). In volcanic settings, rock such as pumice (Minoura and others, 1997) and volcanic glass (Razzhigaeva and others, 2006) may make up significant parts of the deposit. Boulders of 
basalt transported by the Samoan tsunami of September 29, 2009, were found in Samoa (DomineyHowes and Thaman, 2009) (fig. 5). Micas may be concentrated in the upper portions of the deposit or layers within the deposit (Jagodziski and others, 2009). Heavy minerals, including magnetite, amphibole, ilmenite, garnet, zircon, rutile, monazite, and sillimanite, were present in the deposits (Razzhigaeva and others, 2006; Bahlburg and Weiss, 2007; Fritz and others, 2007; Narayana and others, 2007; Jackson, 2008; Jagodziski and others, 2009). Jagodziski and others (2009) found a depletion of tourmalines in the tsunami deposit compared to the underlying deposits.

\section{Organic Material}

Organic material was a common component of the recent tsunami deposits. Large piles of plant debris were common at the wrackline or in flooded areas. Debris at the wrackline was often beyond the limit of sedimentation and not covered by sediment and therefore may not be preserved in the geologic record. Scattered debris and small accumulations of plant material were common at the surface of many tsunami deposits, as were isolated fallen trees (Nanayama and others, 2000; Nanayama and Shigeno, 2006; Razzhigaeva and others, 2006; Monecke and others, 2008; MacInnes and others, 2009a,b; Srinivasalu and others, 2009). The orientation of trees and vegetation were often used by the field surveys to estimate flow direction (Jaffe and others, 2006; Umitsu and others, 2007; Dominey-Howes and Thaman, 2009; Jaffe and others, 2010). Unless rapidly buried, surface vegetation is unlikely to be preserved in the geologic record. Debris in flooded areas has a greater preservation potential because sedimentation rates may be higher, promoting rapid burial, and the potential for erosion of the deposit may be less. Flooding of low-lying land surfaces due to coseismic subsidence along with accumulations of tsunami-deposited debris were documented in Sumatra following the Indian Ocean tsunami (Jaffe and others, 2006). A layer of debris capping the tsunami deposit may be an identifiable characteristic of tsunami deposits preserved in the geologic record. Rooted grass and other vegetation were in some cases found within the tsunami deposit (Nishimura and Miyaji, 1995; Bourgeois and others, 1999; Gelfenbaum and Jaffe, 2003; Jaffe and others, 2006; Umitsu and others, 2007; Kelletat and others, 2007; Higman and Bourgeois, 2008; Morton and others, 2010). In the Kuril Islands, turf and soil flipped over in a landward direction but still attached to the rooted turf surface (MacInnes and others, 2009a,b). A layer of debris in some cases separated deposits from the 2006 and 2007 tsunamis (MacInnes and others, 2009a)

\section{Shells}

Shells and shell fragments were found in the recent tsunami deposits, both within the deposits (fig. 3B) and at the surface (Minoura and others, 1997; Nanayama and others, 2000; Nanayama and Shigeno, 2006; Hori and others, 2007; Choowong and others, 2008; Srinivasalu and others, 2009). Whole shells included mollusks (Razzhigaeva and others, 2006; Jackson, 2008) and sand dollars (Gelfenbaum and Jaffe, 2003). In some cases, shells were abundant in the deposits (Matsumoto and others, 2008) while in other cases, shells were scattered (Morton and others, 2008) or rare (Dawson and others, 1996; Morton and others, 2007).

\section{Foraminifera and Diatoms}

Foraminifera and diatoms were a focus of several tsunami deposit studies. Hawkes and others (2007) used differences between the total number of foraminifera present in the pre-tsunami sediments and the tsunami deposits and in the types present in the assemblages in order to differentiate tsunami deposits from pre-tsunami sediment and to provided estimates of sediment source and wave characteristics. In many cases the total number of foraminifera was greater in the tsunami sediments than in the pre-tsunami sediments. The tsunami sediments also contained both more shelf species than 
the underlying sediments and a more chaotic mix of species. The chaotic mix of species reflects the diverse sources of sediment entrained and deposited by the tsunami. Kokocinski and others (2009) found that diatom assemblages in the tsunami deposits included planktonic and benthic marine species as well as brackish and freshwater species. The assemblages consisted largely of frustules damaged by the tsunami. Foraminiferal assemblages in deposits from the December 12, 2004, tsunami in Tamil Nadu, India, indicate an inner shelf sediment source with a water depth of less than $30 \mathrm{~m}$ (Srinivasalu and others, 2009). Bahlburg and Weiss (2007) also found abundant tests of benthic species from shallow and protected shelf regions in water depth of less than $45 \mathrm{~m}$. Monecke and others (2008) found that in Meulaboh, Sumatra, the diatoms in the tsunami sediments were mostly of fresh water or brackish origin.

In Sumatra, Indonesia, following the December 12, 2004, tsunami, Razzhigaeva and others (2006) found marine, brackish, and freshwater diatom and foraminiferal assemblages in tsunami deposits from Simeulue Island and the Medan coast. On Simeulue Island, the diatoms were dominated by sublittoral species. Tsunami sediments from the Medan coast contained diverse and abundant diatom assemblages including oceanic and neritic species absent from deposits on Simeulue. Razzhigaeva and others (2006) also found that the diatom assemblages found in the tsunami sediments were similar to those of the sediment source with the addition of selected marine species, suggesting that the selected marine species were entrained by the tsunami at sea, while the rest of the assemblage had its source in the sediments. Differences in the abundance and diversity of the diatom assemblages between layers of tsunami deposits can be attributed to the differences in the sedimentation rates of frustules and to the duration of periods of relatively low turbulence between waves. Large, thick-walled frustules were deposited with the coarse-grained sediments, while the current carried the smaller and thin-walled frustules away. In contrast, clayey sediments deposited in depressions during periods of low-turbulence contained a greater abundance of smaller and thin-walled frustules (Razzhigaeva and others, 2006).

\section{Sedimentary Structures and Other Characteristics}

Sedimentary structures were rare or absent in some of the tsunami deposits investigated (Bourgeois and others, 1999; Gelfenbaum and Jaffe, 2003; Monecke and others, 2008). However, a number of sedimentary structures occur, at least locally, within other tsunami deposits. Crossbedding was present in a number of the deposits. Srinivasalu and others (2009) found crossbedding in deposits from Tamil Nadu, India, following the December 12, 2004, tsunami. Morton and others (2007) documented rare crossbedding in deposits from Sri Lanka, also following the December 12, 2004, tsunami. Bahlburg and Weiss (2007) report landward-dipping foresets while Sato and others (1995) report low-angle $\left(5^{\circ}\right)$ seaward-dipping foresets. Current ripples were present in many deposits (Gelfenbaum and Jaffe, 2003; Nanayama and Shigeno, 2006; Choowong and others, 2007; Hawkes and others, 2007; Choowong and others, 2008). Hawkes and others (2007) documented small $1.5 \mathrm{~cm}-\mathrm{high}$ asymmetrical current ripples were draped with a fine organic debris layer $0.5 \mathrm{~cm}$ thick in deposits from the December 26, 2004, tsunami in Thailand. Landward-oriented current dunes were present in deposits in Thailand following the Indian Ocean tsunami; the dunes were formed during the uprush of the tsunami. The size of the bed forms decreased landward. Current ripples formed by the return flow were present in deposits from the December 26, 2004, tsunami in Thailand. (Choowong and others, 2007; Choowong and others, 2008). Morton and other (2010) document sedimentary structures formed by return flow in Chile from the February 27, 2010 tsunami.

Several authors document plane-parallel bedding or laminae within the tsunami deposits (Fritz and others, 2007; Matsumoto and others, 2008; Morton and others, 2008; Nichol and Kench, 2008). Following the Indian Ocean tsunami, in the Maldives, sand sheets had no bedding while sand lobes exhibit continuous landward-dipping tabular bedding (Kench and others, 2007). At Busung and Gudang 
on the island of Simeulue, Indonesia, Razzhigaeva and others (2006) found well-developed horizontal wavy lamination emphasized by thin intercalations of silty-clayey mud and humic material.

Matsumoto and others (2008) documented truncated flame structures in tsunami deposits in Thailand following the 2004 Indian Ocean tsunami and propose a model for their formation. While flame structures are commonly interpreted as dewatering structures, truncated flame structures are formed by a strong unidirectional current and are associated with multilayer tsunami deposits deposited by successive waves of the tsunami. Truncated flame structures are characterized by projections of the fine-grained upper portion of the underlying layer into the coarser grained lower portion of the overlying layer. The tops of the projections are inclined in the downstream direction and have flat truncated tops. Truncated flame structures form when the upper part of a layer deposit by a tsunami wave is deposited during the stagnant period between waves and contains a high percentage of mud, allowing ductile deformation by the subsequent wave. As this next wave passes over the first layer, the drag force induced by the current deforms the top of the underlying layer. Coarse-grained material transported by the second wave fills depressions within the deforming surface. The projecting part of the deformed surface is inclined in the direction of flow and erosion truncates the tops of the projections horizontally. The deposition of sediment with a high percentage of mud in the deformed layer is dependent on the long wave period of the tsunamis, which allows for a stagnant period between waves. Therefore, truncated flame structures may be useful to distinguish tsunami deposits from other events such as storms, which have short wave periods, or river flooding.

At Yala, Sri Lanka, following the 2004 Indian Ocean tsunami, scour and fill structures recorded two distinct erosional and depositional events (Morton and others, 2008). The scour event removed approximately $7 \mathrm{~cm}$ of the upper part of the underlying unit. Post-depositional trample structures (deformation caused by humans or animals walking on the deposit surface) were found in tsunami deposits at Amecosupe, Peru (Jaffe and others, 2003). Of more importance, trample structures also were found in the underlying sand. The underlying trample structures allowed a clear distinction to be made between the tsunami-deposited sand and the very similar beach sand.

Rip-up clasts (clasts of coherent mud and soil eroded from the underlying surface, transported and deposited by the tsunami) were a common feature of recent tsunami deposits (Shi and others, 1995; Nanayama and others, 2000; Gelfenbaum and Jaffe, 2003; Jaffe and others, 2003; Fritz and others, 2007; Hawkes and others, 2007; Morton and others, 2007; Choowong and others, 2008; Matsumoto and others, 2008; Nichol and Kench, 2008; Paris and others, 2009; Srinivasalu and others, 2009; Srisutam and Wagner, 2009). At La Quinta, in Peru, following the June 21, 2001, tsunami, mud rip-up clasts were present in the deposits and larger mud balls (coherent blocks of mud), ripped up from the underlying agricultural soil, were present at the surface (fig. 4) and within the deposit (Jaffe and others, 2003; Morton and others, 2007). Small rip-up clasts of soil were present in deposits in Papua New Guinea from the July 17, 1998, tsunami (Gelfenbaum and Jaffe, 2003) (fig. 3D). In the Kuril Islands, the 1996 tsunami eroded and deposited blocks of sod (MacInnes and others, 2009a,b). These were more abundant and larger (up to $3 \mathrm{~m}$ diameter) on coarser-grained shorelines. At some sites, the soil blocks, composed of turf and soil, were flipped over landward yet still attached to adjacent turf (MacInnes and others, 2009b).

\section{Depositional Environments}

Depositional environment may influence a tsunami deposit either by supplying sediment to the deposit or by altering flow conditions. Some characteristics are independent of, or only weakly dependent on, depositional environment. For example, tsunami deposits in most depositional environments had sharp or erosional basal contacts. In sandy tsunami deposits, regardless of 
depositional environment, normal grading is a common feature. Deposit geometry had some common characteristics that were not dependent on depositional environment. Tsunami deposits tend to thin landward, although not uniformly, after a rapid increase in thickness at the seaward margin of the deposit and may be patchy near the limit of sedimentation. Local variations in thickness may be related to the pre-existing topography, which varies with depositional environment. Where the number of waves controls layering within the tsunami deposit, layering is independent of depositional environment except along the margins or at topographic highs, where only the largest waves inundate. At Amecosupe, Peru, following the June 21, 2001, tsunami, the number of layers within the deposit decreased landwards with increasing elevation (Jaffe and others, 2003).

Tsunami deposits in coastal marsh, lagoon, and tidal channel depositional environments have the greatest preservation potential because high sedimentation rates promote rapid burial. Along with beach deposits, coastal marsh and tidal channel deposits are most likely to be submerged by coseismic subsidence associated with a tsunami. This subsidence further induces burial and preservation of tsunami deposits.

In coastal marsh and lagoonal deposits, mud commonly underlies the tsunami deposits (Jackson, 2008; Higman and Bourgeois, 2008). Buried marsh plants may be preserved and can be used in paleotsunami deposits for radiocarbon dating and, if oriented by the tsunami, can be used to determine flow direction (Atwater and Hemphill-Haley, 1997). Mud is a common component of tsunami deposits in coastal marsh, lagoon, or tidal channel settings and key characteristics for distinguishing tsunami deposits, such as mud rip-up clasts and mud caps, require a source for mud. Underlying mud also provides a sharp contrast with the overlying tsunami-deposited sand, facilitating identification of tsunami deposits. In low-lying areas subject to ponding by the tsunami, deposition of a mud cap may help preserve the deposit and layers within the deposit.

Tsunamis may travel farther inland up tidal channels than along open coast. Banks of tidal channels are often muddy or vegetated. Erosional contacts over muddy substrate may characterize the tsunami deposit or the deposit may directly overlie a vegetated surface. Where tsunamis inundate stream valleys, tsunami deposits can contrast with fluvial sediments in grain size, sedimentary structures, and composition (Jaffe and others, 2003).

On sandy beaches, there is often little contrast between the grain size or composition of the tsunami sediments and the underlying sediments (Jaffe and others, 2003). Where sandy tsunami deposits overlie sandy beach deposits, identification of the tsunami deposit may be difficult. However, sorting during transport and deposition can result in a contrast in grain size between the tsunami deposit and underlying sediments, usually occurring as either coarser sand or a heavy mineral lag at the base of the tsunami deposit. Also, coarser sand entrained from the swash zone may be deposited over finer sand farther inland. Sediment sources for tsunami deposits may include surrounding environments that contain non-sandy material. A mud source must be present in a surrounding environment for mudrelated features such as rip-up clasts, mud layers or a mud cap to be present in a tsunami deposit overlying beach sands. Similarly, large clasts must be present in the tsunami sediment sources for them to be present in the tsunami deposit.

On siliciclastic sandy beaches, most tsunami deposits were composed of siliciclastic sand. In carbonate environments, deposits were usually composed of carbonate sand, but siliclastic material may also be present. Where pebbles and cobbles were present on the beach, they were often present in the deposits. Even where beaches were composed primarily of large grain sizes, such as at La Quinta, Peru, (fig. $4 B$ ), the tsunami deposits inland may contain significant portions of sand (fig. $3 A$ ), suggesting that the sand was entrained in the nearshore (Jaffe and others, 2003). 
On coastlines characterized by ridge-and-swale topography, tsunami deposits typically were thicker in the swales and thinner on the ridges. At Kuala Meurisi, in Sumatra, deposits were up to $34 \mathrm{~cm}$ thick in the swales, while on the ridges, the tsunami deposits ranged from a few centimeters to less than one centimeter. (Jaffe and others, 2006, Gelfenbaum and others, 2007). The thin deposits on the ridges have a lower preservation potential than the thick deposits in the swales. Where the swales are coseismically subsided below tide levels, the preservation potential of the fully or partially submerged tsunami deposits increases. While the original tsunami deposit may be continuous, the geometry of the preserved deposit may be a series of parallel rows of tsunami sediments separated by rows where the tsunami sediment has been eroded away.

Tsunami deposition on islands may differ from mainland settings. On Babi Island, following the December 12, 1992, Flores tsunami, the island's circular shape caused the greatest inundation to be on backside of island (Minoura and others, 1997). Pulau Pangang, a small island off of the north coast of Sumatra near the village of Langi, was almost entirely overwashed except for the top of its small mountain (Razzhigaeva and others, 2006). Erosion extended for up to $200 \mathrm{~m}$ inland on the side facing the tsunami, destroying a forest and palm grove; coral rubble was piled into a rampart $1.5 \mathrm{~m}$ high (Razzhigaeva and others, 2006). Sandy sediments were thickest in the middle and back side of the island (Jaffe and others, 2006). In the Maldives, even though maximum water levels were above the maximum elevation on several of the islands, entire islands were not inundated and deposition extended beyond the high sand ridge into the central depression to only a limited extent (Kench and others, 2007). In places where the tsunami inundated the beach ridge, particularly in areas where heavy vegetation interrupted the tsunami flow, tsunami deposition in some cases took the form of sand lobes rather than sand sheets (Kench and others, 2007; Nichol and Kench, 2008). The sand lobes consist of bodies of sand longer in cross-shore length than width and are commonly convex in cross section and tapered in a landward direction. The sand sheets contained no bedding while the sand lobes exhibited continuous landward-dipping tabular bedding. The limit of sedimentation did not usually penetrate far into the heavily vegetated central depressions of the islands (Kench and others, 2007; Nichol and Kench, 2008)

No trend in sedimentary characteristics of recent tsunami deposits allowed clear differentiation between locally generated tsunamis and tsunamis that have traveled great distances. Deposit geometry, including inland extent and thickness, are, in part, dependent on the size of the tsunami, and for a given tsunami, tsunami height is generally greatest near the source. Deposit geometry also may be controlled by availability of sediment and preexisting topography. Certain coastal configurations can focus tsunami energy and when a tsunami comes ashore in these locations, a tsunami generated at a great distance may produce exceptionally large waves.

\section{Preservation}

While many sedimentary characteristics have been described in studies of recent tsunami deposits, it is important to note (1) which characteristics will be preserved in the geologic record, (2) how they may be altered, and (3) how they will appear in cores, cutbanks, or other methods of investigating paleotsunami deposits. Grain size statistics and grain size trends may be post-deposionally altered. The top of the deposit may be eroded before burial and preservation of the remaining deposit. Mud may infiltrate spaces between sand grains, making originally clean sand deposits appear muddy and shifting the median and mean towards the finer end of the grain-size scale. Vertical grain size trends from deeper within the deposit, such as grading or bedding, may be preserved from erosion but bioturbation may obscure, alter, or destroy original bedding or grain size trends.

Large-scale deposit geometry is likely to be altered over the course of time. The original thickness of deposits may be altered due to erosion or reworking of surface and the sediments may 
become compacted. Seaward margins may be eroded by high tides or storms and landward margins, which are often thin and patchy to begin with, may be obscured, altered or destroyed. To some degree, an estimate of original deposit geometry may be inferred from correlative preserved remnants of a once larger deposit. Chemical alteration may occur, including soil development on surface deposits. Once buried, tsunami deposits composed of clean sand are often the easiest pathway for ground water or roots, particularly when the sand deposits are located in muddy environments, enhancing the potential for post-depositional chemical alteration. In the absence of rapid burial, surface features, such as ripples, may not be preserved.

The sediments typically examined in recent tsunami deposit studies and in the sediments most likely to be preserved in the geologic record are not necessarily the same. Tsunami deposits that have been studied in post-tsunami field surveys are usually subaerially exposed. These deposits will be subjected to high levels of erosion, mechanical and chemical weathering, and bioturbation. Deposits with the highest preservation potential are deposits likely to be rapidly buried. Coseismic subsidence accompanying a tsunami can submerge low-lying tsunami deposits below the high tide line. Figure 8 shows a coseismically subsided marsh at Lhok Kruet, Sumatra, Indonesia, that was inundated by the December 26, 2004, tsunami. In coseismically submerged coastal marshes and tidal channels, the low energy and high sedimentation rates favor rapid burial, creating a high preservation potential. Coseismically subsided marshes preserve paleotsunami deposits in Cascadia (for example, Atwater, 1987). Fully or partially submerged deposits may lack some of the surface features observed in subaerially exposed deposits. For example, mud cracks will not likely be present because surface mud will not get a chance to dry out. More studies of coseismically submerged marshes are needed in order to document any differences in tsunami sedimentation patterns between subaerially exposed tsunami deposits and coseismically submerged tsunami deposits, and to investigate which features of the tsunami deposit will be altered and which will be preserved in a cosiesmically submerged setting.

Original sedimentary structures and contacts may be altered or destroyed by bioturbation. Yawsangratt and others (2009) noted that tsunami deposits in Phang Nga Province, Thailand, had been preserved 3 years after Indian Ocean tsunami but showed signs of bioturbation. Post-depositional changes related to plant growth and root development obscured sedimentary structures within the deposit but the basal contact was still sharp and readily visible. In the Maldives, two years after the Indian Ocean tsunami, deposits were clearly recognizable but modified. There was localized bioturbation by crabs and insects at the landward edge and along the seaward edge, and parts of the tsunami sand sheet had collapsed into the beachface (Nichol and Kench, 2008). 


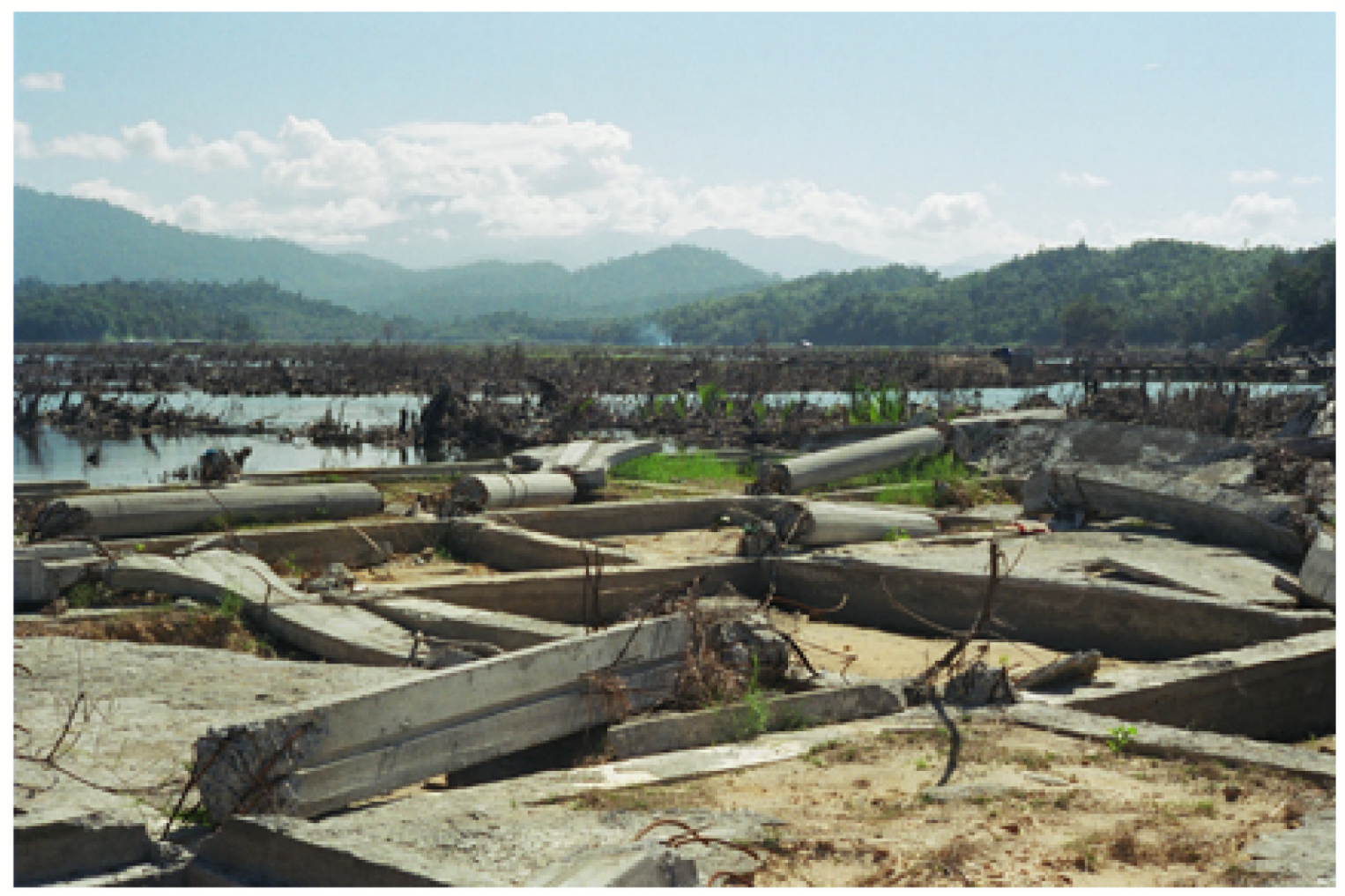

Figure 8. A marsh at Lhok Kruet, Sumatra, Indonesia, coseismically subsided and submerged by the December 26, 2004 earthquake and inundated by the tsunami. Deposits submerged in this marsh may have a greater preservation potential than sediments deposited on the surrounding coastal plain. Note fallen pillars in the foreground indicating the tsunami's inland flow direction.

\section{Developing Tsunami Deposit Identification Criteria}

An approach to identifying tsunami deposits in the geologic record is to identify deposits consistent with tsunami deposition and if possible, to eliminate all other processes that could be responsible for the deposit. In many cases, it will not be possible to eliminate, with any certainty, all other possible depositional processes. If other depositional process cannot be eliminated from consideration, the best that can be done is to determine whether or not a tsunami most likely created the deposit. To determine if a deposit is consistent with tsunami deposition, we have derived a list of tsunami deposit characteristics, based upon recent tsunami deposit studies, which are likely to be preserved in the geologic record. Note that the following list is only to determine consistency with tsunami deposition and does not necessarily eliminate other processes from consideration.

Sharp or erosional basal contact - Most recent tsunami deposits, regardless of depositional setting, had a sharp contact with the underlying material. In many cases, this contact was erosional. A notable exception to an erosional contact is where the tsunami deposit overlies the preexisting vegetated surface. Unless the contact has been altered, such as by bioturbation, a gradual contact is not characteristic of a tsunami deposit.

The deposit geometry forms landward-thinning sand sheets - In most cases, recent tsunami deposits formed sand sheets. The geometry and extent of the sand sheets depended on the size of the tsunami, available source material, and the pre-existing topography. In most cases, the deposit thinned landward, often becoming patchy near the limit of inundation. Portions of the deposit may 
not be preserved, particularly where the deposit becomes thin or patchy near the limit of sedimentation. In a paleotsunami deposit investigation, determining large-scale deposit geometry requires a dense grid of cores, cutbanks, and trenches to map out variations in thickness and extent of the candidate tsunami deposit. In addition, data at additional sites not included in the original sampling grid may be necessary to determine the geometry at the margins of the deposit or to understand local variations in deposit thickness.

Deposit thickness - Most recent tsunami deposits were within a range of 1-30 centimeters thick with thicker accumulations of sediment in swales and depressions. The maximum thickness recorded was $150 \mathrm{~cm}$ (Srinivasalu and others, 2009). Some deposits thinned to less than a centimeter near the limit of inundation or on ridges or other high ground.

Few depositional layers - Recent tsunami deposits typically had 1-4 layers. Each layer usually represented a separate depositional unit formed by separate waves in the tsunami wave train. Where planar bedding or laminations occurred, this was usually within the separate depositional layers. The thickness of individual layers was usually on the order of one to several centimeters, although this was dependent on the overall thickness of the deposit. Where more than one layer was present in a deposit, the number of layers commonly decreased landwards. However, in some cases, the number of layers within a deposit did not change or increased landwards.

Normal grading - Normal grading was a common feature of recent tsunami deposits where the deposit consisted primarily of sand. Where a tsunami deposit was composed of more than one layer, normal grading was often a characteristic of each layer and often only present at the top of a layer.

Normal grading often provided the means of distinguishing layers within a deposit. Normal grading was rarely present throughout the whole deposit. Often, large portions of the deposit were ungraded. Ungraded tsunami deposits were also common and are consistent with tsunami deposition.

Occasionally, inverse grading was seen in a deposit, usually at the base of a layer. While inverse grading is not a defining characteristic of a tsunami deposit, it is important to note that inverse grading does occur in tsunami deposits and that the presence of inverse grading does not eliminate the possibility of the deposit being created by a tsunami.

Mud cap - Where a source for mud was available, a thin layer of mud or finer material often draped the top of the deposit or the top of a layer within the deposit.

Rip-up clasts - Many deposits contained coherent clasts of material ripped up from the underlying substrate (usually mud or soil) within the deposit. This reflects the high energy of the tsunami and the relatively few number of waves. When there are more waves, such as during storms, there is a greater chance that the rip-up clasts would be broken apart.

Boulders - Boulders were a common and defining feature of several tsunami deposits. Most of the boulders were composed of blocks of coral although some were granitic in composition. Boulder deposition was usually restricted to isolated boulders but in some cases boulders were deposited in scattered fields. The boulder source was usually an offshore reef but in some cases, other neighboring environments, including hillsides backing the depositional area, were the source. Boulders may be preserved where other portions of the deposit are eroded away. However, boulder deposition may occur by other depositional processes, including large storms, and these other depositional processes must be considered when evaluating a tsunami origin for boulder deposits. Boulder evidence is best if corroborated by other tsunami evidence.

Sedimentary structures - Sedimentary structures were not common in the tsunami deposits and most of those observed are not unique to tsunamis. One notable exception is truncated flame structures. Although only documented at one site (Matsumoto and others, 2008), truncated flame structures are dependent on processes unique to tsunamis and may be useful in identifying 
paleotsunami deposits. Other structures, such as crossbedding, parallel laminations, or scour and fill structures, may also be characteristic of sediments from surrounding environments or from other depositional process. It is important to note that these other structures can occur in tsunami deposits and that the presence of these structures does not eliminate a tsunami as a possible source.

Coastal sediment source - Tsunami sediments usually have a coastal source. Nearby coastal environments must be examined as potential sediment sources. Composition, grain size, and grain surface texture and marine or coastal fossil assemblages are sedimentary characteristics that can help tie potential tsunami sediments to a coastal source. It is possible that not all of the sediments in a tsunami deposit will have a coastal source. Sediments from interior terrestrial environments, transported to the depositional area by other processes, may be entrained by the tsunami and become a component of the tsunami sediments.

Few recent tsunami deposit investigations observed all ten of these sedimentary characteristics at a single location. It is unlikely that a paleotsunami deposit will exhibit all of these features in a single core, cutbank, and trench, and perhaps not even within an entire site. If a deposit does not contain all of the characteristics listed above, it may still be consistent with tsunami deposition. While local conditions may create exceptions, characteristics that, unless altered, are important for a deposit to be considered consistent with tsunami deposition are (1) a sharp basal contact and (2) a coastal or adjacent sediment source. Thickness usually ranges from 1-20 cm, but may locally be thicker. Other characteristics, such as normal grading, offer a strong supportive argument but are not required for a deposit to be consistent with tsunami deposition.

The sedimentary characteristics of tsunami deposits presented here should be incorporated into site-specific identification criteria that take into account depositional environment, surrounding environments, and sediment sources. All other depositional processes that could account for the deposit must be considered and the differences between the sedimentary characteristics of deposits by these processes contrasted with those of tsunami deposits. Different characteristics may be necessary to evaluate each process. For example, a coastal sediment source for a deposit may eliminate fluvial deposition while normal grading and layering may be help eliminate storm deposition from consideration (Morton and others, 2007). The geologic potential for tsunamis at the site and the potential tsunami sources should be considered in all tsunami deposit studies. Also, inundation modeling may be useful to determine if the runup and inundation suggested by candidate tsunami deposits is compatible with potential tsunami sources. Available geological, historical, and paleotsunami studies from nearby or similar environments are also useful to supplement the tsunami deposit identification criteria presented in this report.

\section{Conclusions}

Investigations of recent tsunamis have provided a wealth of data on tsunami deposit sedimentary characteristics. Sedimentary characteristics common to the recent tsunami deposits studied include a sharp or erosional basal contact and deposits of sand sheets composed of few layers. The deposits were often massive, but normal grading, often within each layer, was a common and defining feature of the deposits. Massive deposits were also common, and in a few cases, inverse grading was observed. Boulders were a feature of some tsunami deposits. In muddy environments, rip-up clasts of mud and soil were common and mud often capped the deposit or layers within the deposit. Sedimentary structures were rare or absent from many of the tsunami deposits, but crossbedding and plane parallel laminations were documented. Truncated flame structures were observed in one of the deposits and this is directly and uniquely related to tsunami processes. 
Tsunami sediments have a coastal or nearshore marine sediment source with possibly a small terrestrial component derived from erosion of the depositional environment or adjacent inland environments. Characteristics such as grain size, grain surface texture, and composition are more dependent on the sediment source than on the tsunami process. These characteristics are useful in linking a deposit to a coastal sediment source, which contributes to determining a tsunami origin for a sedimentary deposit, but cannot be used to distinguish tsunami sediments from deposits formed by other processes that tap a similar sediment source, such as storm deposits.

The preservation potential of the tsunami sediments and the sedimentary characteristics within the deposit will influence which characteristics will be useful as tsunami identification criteria and in which environments paleotsunami deposits will likely be found. Low-lying coastal marshes, tidal channels, and lagoons have the greatest preservation potential. They provide a source for mud, necessary for defining characteristics such as mud caps and rip-up clasts. The basal mud and often-vegetated soil provides a sharp contrast with tsunami-deposited sand that may be uncommon in these environments.

To plan for and help mitigate tsunami hazards, paleotsunami deposit studies are a valuable part of efforts to assess the tsunami hazard at a given site. Sedimentary characteristics derived from recent tsunami deposits provide a means of determining whether deposits preserved in the geologic record are consistent with a tsunami origin. These sedimentary characteristics of recent tsunami deposits, when considered in addition with other geological, historical, paleotsunami, and modeling studies, provide a means for developing the site-specific tsunami deposit identification criteria necessary to conduct effective paleotsunami deposit surveys.

\section{Acknowledgements}

This research was funded by the US Nuclear Regulatory Commission and US Geological Survey Coastal and Marine Catastrophic Hazards Project. The views expressed are not necessarily those of the US Nuclear Regulatory Commission. We would like to thank Steve Watt for his help with GIS and in developing the map of tsunami deposits included this report and in the Database of Recent Tsunami Deposits (Peters and Jaffe, 2010). Mark Buckley and Amy Draut provided thoughtful reviews that greatly improved this report.

\section{References Cited}

Atwater, B., 1987, Evidence for great Holocene earthquakes along the outer coast of Washington state: Science, v. 236, p. 942-944.

Atwater, B., and Hemphill-Haley, E., 1997, Recurrence intervals for great earthquakes of the past 3500 years at northeastern Willapa Bay, Washington: U.S. Geological Survey Professional Paper $1576,108 \mathrm{p}$.

Bahlburg, H., and Weiss, R., 2007, Sedimentology of the December 26, 2004, Sumatra tsunami deposits in eastern India (Tamil Nadu) and Kenya: International Journal of Earth Science, doi:10.1007/s00531-006-0148-9.

Benson, B.E., Grimm, K.A., and Clague, J.J., 1997, Tsunami deposits beneath tidal marshes on northwestern Vancouver Island, British Columbia: Quaternary Research, v. 48, p. 192-204.

Bourgeois, J., Petroff, C., Yeh, H., Titov, V., Synolakis, C., Benson, B., Kuroiwa, J., Lander, J. and Norabuena, E., 1999, Geologic setting, field survey and modeling of the Chimbote, northern Peru tsunami of 21 February 1996: Pure and Applied Geophysics, v. 154, p. 513-540.

Choowong, M., Murakoshi, N., Hisada, K., Charusiri, P., Charoentitirat, T., Chutakositkanon, V., Jankaew, K., Kanjanapayont, P., and Phantuwongraj, S., 2008, 2004 Indian Ocean tsunami inflow and outflow at Phuket, Thailand: Marine Geology, v. 248, p. 179-192. 
Choowong, M., Murakoshi, N., Hisada, K., Charusiri, V., Charoentitirat, T., Chutakositkanon, V., Jankaew, K., and Kanjanapayont, P., 2007, Erosion and deposition by the 2004 Indian Ocean Tsunami in Phuket and Phang-nga Provinces, Thailand: Journal of Coastal Research, v. 23, no. 5, p. 1270-1276.

Dawson, A.G., Shi, S., Dawson, S., Takahashis, T., and Shutos, N., 1996, Coastal sedimentation associated with the June 2nd and 3rd, 1994 tsunami in Rajegwesi, Java: Quaternary Science Reviews, v. 15, p. 901-912.

Dawson, A.G., and Shi, S.Z., 2000, Tsunami deposits: Pure and Applied Geophysics, v. 157, p. 875897.

Dengler, L.D., Borrero, J., Gelfenbaum, G. Jaffe, B., Okal, E., Ortiz, M., and Titov, V., 2003, Tsunami, in Southern Perú Earthquake of 23 June, 2001 Reconnaissance Report: Earthquake Spectra, supplement to vol. 19, p. 115-144.

Dominey-Howes, D., and Thaman, R., 2009, UNESCO-IOC International Tsunami Survey Team Samoa (ITST Samoa) Interim Report of Field Survey, 14th - 21st October 2009: Australian Tsunami Research Centre Miscellaneous Report No. 2, October 2009, 190 p.

Eaton, J.P., Richter, D.H., and Ault, W.U., 1961, The tsunami of May 23, 1960, on the Island of Hawaii: Seismological Society of America Bulletin, v. 51, p. 135-157.

Fritz, H.M., Kongko, W., Moore, A., McAdoo, B., Goff, J., Harbitz, C., Uslu, B., Kalligeris, N., Suteja, D., Kalsum, K., Titov,V., Gusman, A., Latief, H. Santoso, E., Sujoko, S., Djulkarnaen, D., Sunendar, H., and Synolakis. C., 2007, Extreme runup from the 17 July 2006 Java tsunami: Geophysical Research Letters, v. 34, L12602, doi:10.1029/2007GL029404.

Gelfenbaum, G., and Jaffe, B., 2003, Erosion and sedimentation from the 17 July, 1998 Papua New Guinea Tsunami: Pure and Applied Geophysics, v. 160, p. 1969-1999, doi:10.1007/s00024-0032416-y.

Gelfenbaum, G., Vatvani, D., Jaffe, B., and Dekker, F., 2007, Tsunami inundation and sediment transport in vicinity of coastal mangrove forest: Coastal Sediments ’07, v. 2, p. 1117-1128.

Goff, J., Liu, P. L.-F., Higman, B., Morton, R., Jaffe, B.E., Fernando, H., Lynett, P., Fritz, H., Synolakis, C., and Fernando, S., 2006, Sri Lanka field survey after the December 2004 Indian Ocean tsunami: Earthquake Spectra, v. 22, p. S155-S172.

Goff, J., McFadgen, B.G., and Chague-Goff, C., 2004, Sedimentary differences between the 2002 Easter storm and the 15th-century Okoropunga tsunami, southeastern North Island, New Zealand: Marine Geology, v. 204, p. 235-250.

González, F.I., Geist, E.L., Jaffe, B., Kanoglu, U., Mofjeld, H., Synolakis, C.E., Titov, V.V., Arcas, D., Bellomo, D., Carlton, D., Horning, T., Johnson, J. Newman, J., Parsons, T., Peters, R., Peterson, C., Priest, G., Venturato, A., Weber, J., Wong, F., Yalciner, A., 2009, Probabilistic tsunami hazard assessment at Seaside, Oregon, for near- and far-field seismic sources: Journal of Geophysical Research, v. 114, C11023, doi:10.1029/2008JC005132

Goto, K., Okada, K., Imamura, F., 2009, Importance of the initial waveform and coastal profile for tsunami transport of boulders: Polish Journal of Environmental Studies, v. 18, p. 53-61.

Hawkes, A.D., Bird, M., Cowie, S., Grundy-Warr, C., Horton, B.P., Hwai, A.T.S., Law, L., Macgregor, C., Nott, J., Ong, J.E., Rigg, J., Robinson, R., Tan-Mullins, M., Sa, T.T., Yasin, Z. and Aik, L.W., 2007, Sediments deposited by the 2004 Indian Ocean Tsunami along the MalaysiaThailand Peninsula: Marine Geology, v. 242, p. 169-190.

Higman, B., and Joanne Bourgeois, J., 2008, Deposits of the 1992 Nicaragua Tsunami, in Tsunamiites_Features and Implications: Elsevier, p. 81-103, doi:10.1016/S00704571(07)00006-4. 
Hori, K., Kuzumoto, R., Hirouchi, D., Umitsu, M., Janjirawuttikul, N., and Patanakanog, B., 2007, Horizontal and vertical variation of 2004 Indian tsunami deposits: an example of two transects along the western coast of Thailand: Marine Geology, v. 239, p. 163-172.

Jackson, K.L., 2008, Paleotsunami history recorded in Holocene coastal lagoon sediments, southeastern Sri Lanka: University of Miami, M.S. thesis, 234 p.

Jaffe, B., Gelfenbaum, G., Rubin, D., Peters, R., Anima, R., Swensson, M., Olcese, D., Bernales L., Gomez, J., and Riega, P., 2003, Tsunami deposits: Identification and interpretation of tsunami deposits from the June 23, 2001 Perú tsunami: Coastal Sediments '03 Proceedings, 13 p.

Jaffe, B.E., Borrero, J.C., Prasetya, G.S., Peters, R., McAdoo, B., Gelfenbaum, G., Morton, R., Ruggiero, P., Higman, B., Dengler, L., Hidayat, R., Kingsley, E., Kongko, W., Lukijanto, Moore, A., Titov, V., and Yuliantom, E., 2006, Northwest Sumatra and offshore islands field survey after the December 2004 Indian Ocean tsunami: Earthquake Spectra, v. 22, p. S105S135.

Jaffe, B., and Gelfenbaum, G., 2007, A simple model for calculating tsunami flow speed from tsunami deposits: Sedimentary Geology, v. 200, p. 347-361.

Jaffe, B., Gelfenbaum, G., Rubin, D., Peters, R., Anima, R., Swensson, M., Olcese, D., Bernales L., Gomez, J., and Riega, P., 2003, Tsunami deposits: Identification and interpretation of tsunami deposits from the June 23, 2001 Perú tsunami: Coastal Sediments '03 Proceedings, 13 p.

Jaffe, B.E., Borrero, J.C., Prasetya, G.S., Peters, R., McAdoo, B., Gelfenbaum, G., Morton, R., Ruggiero, P., Higman, B., Dengler, L., Hidayat, R., Kingsley, E., Kongko, W., Lukijanto, Moore, A., Titov, V., and Yuliantom, E., 2006, Northwest Sumatra and offshore islands field survey after the December 2004 Indian Ocean tsunami: Earthquake Spectra, v. 22, p. S105S135.

Jaffe, B.E., Gelfenbaum, G., Buckley, M.L., Watt, S., Apotsos, A., Stevens, A.W., and Richmond, B.M., 2010, The limit of inundation of the September 29, 2009 on Tutuila, American Samoa: U.S. Geological Survey Open-File Report 2010-1018, 27p. [http://pubs.usgs.gov/of/2010/1018/]

Jagodziski, R., Sternal, B., Szczuciski, W., and Lorenc, S., 2009, Heavy minerals in 2004 tsunami deposits on Kho Khao Island, Thailand: Polish Journal of Environmental Studies, v. 18, p. 103110.

Kelletat, D., Scheffers, S.R., and Scheffers, A., 2007, Field signatures of the SE-Asian mega-tsunami along the west coast of Thailand compared to Holocene Paleo-tsunami from the Atlantic region: Pure and Applied Geophysics, v. 164, p. 413-431.

Kelsey, H.M., Witter, R.C., and Hemphill-Haley, E., 2002, Plate-boundary earthquakes and tsunamis of the past 5,500 yr, Sixes River estuary, southern Oregon: Geological Society of America Bulletin, v. 114, p. 298-314.

Kench, P.S., Nichol, S.L., Smithers, S.G., McLean, R.F., and Brander, W., 2007, Tsunami as agents of geomorphic change in mid-ocean reef islands: Geomorphogy, v. 95, p. 361-383.

Kokocinski, M., Szczucinski, W., Zgrundo, A., and Ibragimow, A., 2009, Diatom assemblages in 26 December 2004 tsunami deposits from coastal zone of Thailand, as sediment provenance indicators: Polish Journal of Environmental Studies, v. 18, p. 93-101.

Kon'no, E., Iwai, J., Kitamura, N., Kotaka, T. Mii, H. Nakagawa, H. Onuki, Y. Shibata T., and Takayanagi, Y., 1961, Geological observations of the Sanriku coastal region damaged by the tsunami due to the Chile earthquake in 1960 (in Japanese with English abstract): Contributions from the Institute of Geology and Paleontology, Tohoku University, v. 52, 40 p.

Kortekaas, S., and Dawson, A.G., 2007, Distinguishing tsunami and storm deposits: An example from Martinhal, SW Portugal: Sedimentary Geology, v. 200, p. 208-221. 
Kozak, L., and Siepak, J., 2009, The chemical study of tsunami deposits in south Thailand - Review: Polish Journal of Environmental Studies, v. 18, p. 137-139.

Lay, T., Ammon, C.J., Kanamori, H., Rivera, L., Koper, K.D., and Hutko, A.R., 2010, The 2009 Samoa-Tonga great earthquake triggered doublet: Nature, v. 466, p. 964-968.

Lay, T., Kanamori, H., Ammon, C.J., Nettles, M., Ward, S.N., Aster, R.C., Beck, S. L., Bilek, S. L., Brudzinski, M.R., Butler, R., DeShon, H.R., Ekström, G., Satake, K., and Sipkin, S., 2005, The great Sumatra-Andaman earthquake of 26 December 2004: Science, v. 308, p. 1127-1133.

MacInnes, B.T., Bourgeois, J., Pinegina, T.K., and Kravchunovskaya, E.A., 2009a, Tsunami geomorphology: Erosion and deposition from the 15 November 2006 Kuril Island tsunami: Geology, v. 37, p. 995-998.

MacInnes, B.T., Pinegina, T.K., Bourgeois, J., Razzhigaeva, N.G., Kaistrenko, V.M., and Kravchunovskaya, E.A., 2009b, Field survey and geological effects of the 15 November 2006 Kuril Tsunami in the Middle Kuril Islands: Pure and Applied Geophysics, v. 166, p. 9-36.

Matsumoto, D., Naruse, H., Fujino, S., Surphawajruksakul, A., Jarupongsakul, T., Sakakura, N., and Murayama, M., 2008, Truncated flame structures within a deposit of the Indian Ocean Tsunami: evidence of syn-sedimentary deformation: Sedimentology, v. 55, p. 1559-1570.

McAdoo, B.G., Fritz, H., Jackson, K.L., Kalligeris, N, Kruger, J., Bonte-Grapentin, M., Moore, A.L., Rafiau, W.B., Billy, D., and Tiano, B., 2008, Solomon Islands tsunami, one year later: EOS, Transactions, American Geophysical Union, v. 89, no. 18, p. 169-170.

Minoura, K., Imamura, F., Takahashi, T., Shuto, N., 1997, Sequence of sedimentation processes caused by the 1992 Flores tsunami: Evidence from Babi Island: Geology, v. 25, no. 6, p. 523-526.

Monecke, K., Finger, W., Klarer, D., Kongko, W., McAdoo, B.G.,. Moore, A.L., and Sudrajat, S.U., 2008, A 1,000-year sediment record of tsunami recurrence in northern Sumatra: Nature, v. 455, p. $1232-1234$.

Moore, A., and Jaffe, B., 2007, Geologic evidence of tsunamis, in Gonzalez, F.I., Scientific and technical issues in tsunami hazard assessment of nuclear power plant sites: NOAA Technical Memorandum OAR PMEL-136, Pacific Marine Environmental Laboratory, Seattle, Wash., 125 p. + appendices on CD.

Moore, A.L., McAdoo, B.G., and Ruffman, A., 2007, Landward fining from multiple sources in a sand sheet deposited by the 1929 Grand Banks tsunami, Newfoundland: Sedimentary Geology, 200 (3-4), 336-346.

Morton, R.A., Buckley, M.L., Gelfenbaum, G., Richmond, B.M., Cecioni, A., Artal, O., Hoffman, C., and Perez, F., 2010, Geological impacts and sedimentary record of the February 27, 2010, Chile tsunami; La Trinchera to Concepcion: U.S. Geological Survey Open-File Report 2010-1116, 22 p. [http://pubs.usgs.gov/of/2010/1116/]

Morton, R., Jaffe, B., and Gelfenbaum, G., 2007, Physical criteria for distinguishing sandy tsunami and storm deposits using modern examples: Sedimentary Geology, v. 200, p. 184-207.

Morton, R.A., Goff, J.R., and Nichol, S.L., 2008, Hydrodynamic implications of textural trends in sand deposits of the 2004 tsunami in Sri Lanka: Sedimentary Geology, v. 207, p. 56-64.

Nanayama, F., Shigeno, K., 2006, Inflow and outflow facies from the 1993 tsunami southwest Hokkaido: Sedimentary Geology, v. 187, p. 139-158.

Nanayama, F., Shigeno, K., Satake, K., Shimokaka, K., Koitabashi, S., Miyasaka, S., and Ishii, M., 2000, Sedimentary differences between the 1993 Hokkaido-nansei-oki tsunami and the 1959 Miyakojima typhoon at Taisei, southwestern Hokkaido, northern Japan: Sedimentary Geology, v. 135 , p. 255-264. 
Narayana, A.C., Tatavarti, R., Shinu, N. and Subeer, A., 2007, Tsunami of December 26, 2004 on the southwest coast of India: Post-tsunami geomorphic and sediment characteristics: Marine Geology, v. 242, p. 155-168.

Nichol, S.L., and Kench, P.S., 2008, Sedimentology and preservation potential of carbonate sand sheets deposited by the December 2004 Indian Ocean tsunami: South Baa Atoll, Maldives: Sedimentology, v. 55, p. 1173-1187.

Nishimura, Y., and Miyaji, N., 1995, Tsunami deposits from the 1993 Southwest Hokkaido Earthquake and the 1640 Hokkaido Komagatake Eruption, northern Japan: Pure and Applied Geophysics, v. 144, p. 719-733.

Paris, R., Wassmer, P., Sartohadi, J., Lavigne, F., Barthomeuf, B., Desgages, E., Grancher, D., Baumert, P., Vautier, F., Brunstein, D. and Gomez, C., 2009, Tsunamis as geomorphic crises: Lessons from the December 26, 2004 tsunami in Lhok Nga, West Banda Aceh (Sumatra, Indonesia): Geomorphology, v. 104, p. 59-72.

Peters, R. and Jaffe, B., 2010, Database of recent tsunami deposits: U.S. Geological Survey Open-File Report 2010-1172, 12 p. and database. [http://pubs.usgs.gov/of/2010/1172/]

Priest, G.R., Myers, E., Baptista, A., Kamphaus, R., and Peterson, C.D., 1997, Tsunami hazard map of the Yaquina Bay area, Lincoln County, Oregon: Oregon Department of Geology and Mineral Industries Interpretive Map Series IMS-2, 1 sheet, scale 1:12,000.

Razzhigaeva, N.G., Ganzei, L.A., Grebennikova, T.A., Ivanova, E.D., and Kaistrenko, V.M., 2006, Sedimentation particularities during the tsunami of December 26, 2004 in Northern Indonesia: Simelue Island and the Medan Coast of Sumatra Island: Oceanology, v. 46, p. 875-890.

Richmond, B.M., Jaffe, B.E., Gelfenbaum, G., and Morton, R.A., 2006, Geologic impacts of the 2004 Indian Ocean tsunami on Indonesia, Sri Lanka, and the Maldives, in Tsunamis, hurricanes and neotectonics as driving mechanisms in coastal evolution, Proceedings of the Bonaire Field Symposium, March 2-6, 2006: Zeitschrift für Geomorphologie, Supplementbände v. 146, p. 235251.

Ross, S., Boore, D.M., Fisher, M.A., Frankel, A.D., Geist, E.L., Hudnut, K.W., Kayen, R.E., Lee, H.J., Normark, W.R., and Wong, F.L., 2004, Comments on potential geologic and seismic hazards affecting coastal Ventura County, California: U.S. Geological Survey Open-File Report 20041286. $20 \mathrm{p}$.

Sato, H., Shimamoto, T., Tsutsumi, A., and Kawamoto, E., 1995, Onshore tsunami deposits caused by the 1993 southwest Hokkaido and 1983 Japan-Sea earthquakes: Pure and Applied Geophysics, v. 144, p. 693-717.

Schlichting, R.B., and Peterson, C.D., 2006, Mapped overland distance of paleotsunami high-velocity inundation in back-barrier wetlands of the central Cascadia margin, U.S.A.: Journal of Geology, v. 114 , no. 5 , p. 577-592.

Shepard, F.P., Macdonald, G.A., and Cox, D.C., 1950, The tsunami of April 1, 1946: University of California, Scripps Institute, Oceanography Bulletin, v. 5, p. 391-528.

Shi, S., Dawson, A.G., and Smith, D.E., 1995, Coastal sedimentation associated with the December 12th, 1992 tsunami in Flores, Indonesia: Pure and Applied Geophysics, v. 144, p. 525-536.

Soulsby, R.L., Smith, D.E., and Ruffman, A., 2007, Reconstructing tsunami runup from sedimentary characteristics - a simple mathematical model: Coastal Sediments 2007, p. 1075-1088.

Srinivasalu, S., Rajeshwara Rao, N., Thangadurai, N., Jonathan, M. P., Roy P. D., Ram Mohan V., and Saravanan, P., 2009, Characteristics of 2004 tsunami deposits of the northern Tamil Nadu coast, southeastern India: Boletín de la Sociedad Geológica Mexicana, v. 61, p. 111-118. 
Srisutam, C., and Wagner, J.F., 2009, Multiple layer identification and transportation pattern analysis for onshore tsunami deposit as the extending tsunami data - a case study from the Thai Andaman coast: Science of Tsunami Hazards, v. 28, p. 205-217.

Szczucinski, W., Niedzielski, P., Kozac, L., Frankowski , M., Ziola, A., and Lorenc, S., 2007, Effects of rainy season on mobilization of contaminants from tsunami deposits left in a coastal zone of Thailand by the 26 December 2004 tsunami: Environmental Geology, v. 53, p. 253-264.

Szczucinski, W., Niedzielski, P., Rachlewicz, G., Sobczynski, T., Ziola, A., Kowalski, A., and Lorenc, S., Siepak, J., 2005, Contamination of tsunami sediments in a coastal zone inundated by the 26 December 2004 tsunami in Thailand: Environmental Geology, v. 49, p. 321-331.

Titov, V., Rabinovich, A.B., Mofjeld, H.O., Thomson, R.E., and Gonzalez, F.I., 2005, The global reach of the 26 December 2004 Sumatra tsunami: Science, v. 309, no. 5743, p. 2045-2048.

Tsunami Pilot Study Working Group, 2006, Seaside, Oregon tsunami pilot study - Modernization of FEMA flood hazard maps: NOAA OAR Special Report, NOAA/OAR/PMEL, Seattle, WA, 94 p. +7 appendices.

Tuttle, M.P., Ruffman, A., Anderson, T., and Jeter, H., 2004, Distinguishing tsunami from storm deposits in Eastern North America: the 1929 Grand Banks tsunami versus the 1991 Halloween storm: Seismological Research Letters, v. 75, p. 117-131.

Umitsu, M., Tanavud, C., and Patanakanog, B., 2007, Effects of landforms on tsunami flow in the plains of Banda Aceh, Indonesia, and Nam Khem, Thailand: Marine Geology, v. 242, p. 141-153.

U.S. Geological Survey, 2009, Preliminary earthquake report. National Earthquake Information Center: U.S. Geological Survey Web site. [accessed February 12, 2010 at http://earthquake.usgs.gov/earthquakes/recenteqsww/Quakes/us2009mdbi.php].

Walsh, T.J., Caruthers, C.G., Heinitz, A.C., Meyers, E.P. III, Baptista, A.M., Erdakos, G.B., and Kamphaus, R.A., 2000, Tsunami hazard map of the southern Washington coast: Modeled Tsunami Inundation from a Cascadia Subduction Zone Earthquake: Washington Division of Geology and Earth Resources, Geologic Map GM-49.

Wright, C., and Mella, A., 1963, Modifications to the soil pattern of south-central Chile resulting from seismic and associated phenomena during the period May to August 1960: Bulletin of the Seismological Society of America, v. 53, p. 1367-1402.

Yawsangratt, S., Szczucinski, W., Chaimanee, N., Jagodzinski, R., Lorenc, S., Chatprasert, S., Saisuttichai D. and Tepsuwan, T., 2009, Depositional effects of 2004 tsunami and hypothetical paleotsunami near Thap Navy Base in Phang Nga Province, Thailand: Polish Journal of Environmental Studies, v. 18, p. 17-23.

\section{Appendix}

Site locations, and references for recent tsunami deposit sites included in this study and in the Database of recent tsunami deposits (Peters and Jaffe, 2010). Latitude is given in decimal degrees. A positive latitude indicates north latitude and a negative latitude indicates south latitude. Longitude is given in decimal degrees. A positive longitude indicates east longitude and a negative longitude indicates west longitude.

\begin{tabular}{|c|c|c|l|l|l|}
\hline Site & $\begin{array}{c}\text { Latitude } \\
\text { (decimal } \\
\text { degrees) }\end{array}$ & $\begin{array}{c}\text { Longitude } \\
\text { (decimal } \\
\text { degrees) }\end{array}$ & $\begin{array}{c}\text { Name/designation of } \\
\text { tsunami }\end{array}$ & $\begin{array}{c}\text { Date of } \\
\text { tsunami }\end{array}$ & \multicolumn{1}{|c|}{ Reference } \\
\hline La Trinchera & -35.108 & -72.201 & Chile & $\begin{array}{l}\text { February 27, } \\
2010\end{array}$ & $\begin{array}{l}\text { Morton and others, } \\
2010\end{array}$ \\
\hline
\end{tabular}




\begin{tabular}{|c|c|c|c|c|c|}
\hline Site & $\begin{array}{l}\begin{array}{l}\text { Latitude } \\
\text { (decimal } \\
\text { degrees) }\end{array}\end{array}$ & $\begin{array}{c}\text { Longitude } \\
\text { (decimal } \\
\text { degrees) }\end{array}$ & $\begin{array}{c}\text { Name/designation of } \\
\text { tsunami }\end{array}$ & $\begin{array}{l}\text { Date of } \\
\text { tsunami }\end{array}$ & Reference \\
\hline Constitucion & -35.306 & -72.399 & Chile & $\begin{array}{l}\text { February } 27, \\
2010\end{array}$ & $\begin{array}{l}\text { Morton and others, } \\
2010\end{array}$ \\
\hline Purema & -36.446 & -72.883 & Chile & $\begin{array}{l}\text { February } 27, \\
2010\end{array}$ & $\begin{array}{l}\text { Morton and others, } \\
2010\end{array}$ \\
\hline Coliumo & -36.557 & -72.956 & Chile & $\begin{array}{l}\text { February } 27, \\
2010\end{array}$ & $\begin{array}{l}\text { Morton and others, } \\
2010\end{array}$ \\
\hline Talcahuano & -36.735 & -73.053 & Chile & $\begin{array}{l}\text { February } 27, \\
2010\end{array}$ & $\begin{array}{l}\text { Morton and others, } \\
2010\end{array}$ \\
\hline $\begin{array}{l}\text { Tutuila, American } \\
\text { Samoa }\end{array}$ & -14.332 & -170.799 & Samoa & $\begin{array}{l}\text { September } \\
29,2009\end{array}$ & $\begin{array}{l}\text { Jaffe and others, } \\
2010\end{array}$ \\
\hline Upolu, Samoa & -14.035 & -171.682 & Samoa & $\begin{array}{l}\text { September } \\
29,2009\end{array}$ & $\begin{array}{l}\text { Dominey-Howes and } \\
\text { Thaman, } 2009\end{array}$ \\
\hline $\begin{array}{l}\text { Ghizo, Soloman } \\
\text { Islands }\end{array}$ & -8.081 & 156.796 & Solomon Islands & $\begin{array}{l}\text { April 2, } \\
2007\end{array}$ & $\begin{array}{l}\text { McAdoo and others, } \\
2008\end{array}$ \\
\hline $\begin{array}{l}\text { Ranongga, Soloman } \\
\text { Islands }\end{array}$ & -8.066 & 156.558 & Solomon Islands & $\begin{array}{l}\text { April 2, } \\
2007\end{array}$ & $\begin{array}{l}\text { McAdoo and others, } \\
2008\end{array}$ \\
\hline $\begin{array}{l}\text { Simbo, Soloman } \\
\text { Islands }\end{array}$ & -8.292 & 156.520 & Solomon Islands & $\begin{array}{l}\text { April 2, } \\
2007\end{array}$ & $\begin{array}{l}\text { McAdoo and others, } \\
2008\end{array}$ \\
\hline Njari, Soloman Islands & -8.017 & 156.750 & Solomon Islands & $\begin{array}{l}\text { April 2, } \\
2007\end{array}$ & $\begin{array}{l}\text { McAdoo and others, } \\
2008\end{array}$ \\
\hline $\begin{array}{l}\text { Makuti, Soloman } \\
\text { Islands }\end{array}$ & -8.133 & 156.967 & Solomon Islands & $\begin{array}{l}\text { April 2, } \\
2007\end{array}$ & $\begin{array}{l}\text { McAdoo and others, } \\
2008\end{array}$ \\
\hline $\begin{array}{l}\text { Dushnaya Bay central, } \\
\text { Kuril Islands, Russia }\end{array}$ & 47.062 & 152.175 & Kuril Islands & $\begin{array}{l}\text { November } \\
15,2006\end{array}$ & $\begin{array}{l}\text { MacInnes and others, } \\
\text { 2009a, }\end{array}$ \\
\hline $\begin{array}{l}\text { South Bay, Kuril } \\
\text { Islands, Russia }\end{array}$ & 48.042 & 153.249 & Kuril Islands & $\begin{array}{l}\text { November } \\
15,2006\end{array}$ & $\begin{array}{l}\text { MacInnes and others, } \\
\text { 2009a }\end{array}$ \\
\hline $\begin{array}{l}\text { Ainu Bay, Kuril } \\
\text { Islands, Russia }\end{array}$ & 48.044 & 153.225 & Kuril Islands & $\begin{array}{l}\text { November } \\
15,2006\end{array}$ & $\begin{array}{l}\text { MacInnes and others, } \\
\text { 2009a }\end{array}$ \\
\hline $\begin{array}{l}\text { Ainu Bay, Kuril } \\
\text { Islands, Russia }\end{array}$ & 48.043 & 153.227 & Kuril Islands & $\begin{array}{l}\text { November } \\
15,2006\end{array}$ & $\begin{array}{l}\text { MacInnes and others, } \\
\text { 2009a }\end{array}$ \\
\hline $\begin{array}{l}\text { Dushnaya Bay, Kuril } \\
\text { Islands, Russia }\end{array}$ & 47.045 & 152.159 & Kuril Islands & $\begin{array}{l}\text { November } \\
15,2006\end{array}$ & $\begin{array}{l}\text { MacInnes and others, } \\
\text { 2009a }\end{array}$ \\
\hline $\begin{array}{l}\text { Dushnaya Bay, Kuril } \\
\text { Islands, Russia }\end{array}$ & 47.056 & 152.167 & Kuril Islands & $\begin{array}{l}\text { November } \\
15,2006\end{array}$ & $\begin{array}{l}\text { MacInnes and others, } \\
\text { 2009a }\end{array}$ \\
\hline $\begin{array}{l}\text { Dushnaya Bay, Kuril } \\
\text { Islands, Russia }\end{array}$ & 47.058 & 152.169 & Kuril Islands & $\begin{array}{l}\text { November } \\
15,2006\end{array}$ & $\begin{array}{l}\text { MacInnes and others, } \\
\text { 2009a }\end{array}$ \\
\hline $\begin{array}{l}\text { Dushnaya Bay, Kuril } \\
\text { Islands, Russia }\end{array}$ & 47.061 & 152.173 & Kuril Islands & $\begin{array}{l}\text { November } \\
15,2006\end{array}$ & $\begin{array}{l}\text { MacInnes and others, } \\
\text { 2009a }\end{array}$ \\
\hline $\begin{array}{l}\text { Dushnaya Bay, Kuril } \\
\text { Islands, Russia }\end{array}$ & 47.064 & 152.177 & Kuril Islands & $\begin{array}{l}\text { November } \\
15,2006\end{array}$ & $\begin{array}{l}\text { MacInnes and others, } \\
\text { 2009a }\end{array}$ \\
\hline $\begin{array}{l}\text { Dushnaya Bay, Kuril } \\
\text { Islands, Russia }\end{array}$ & 47.070 & 152.188 & Kuril Islands & $\begin{array}{l}\text { November } \\
15,2006\end{array}$ & $\begin{array}{l}\text { MacInnes and others, } \\
\text { 2009a }\end{array}$ \\
\hline $\begin{array}{l}\text { Dushnaya Bay, Kuril } \\
\text { Islands, Russia }\end{array}$ & 47.075 & 152.195 & Kuril Islands & $\begin{array}{l}\text { November } \\
15,2006\end{array}$ & $\begin{array}{l}\text { MacInnes and others, } \\
\text { 2009a }\end{array}$ \\
\hline $\begin{array}{l}\text { Dushnaya Bay, Kuril } \\
\text { Islands, Russia }\end{array}$ & 47.078 & 152.206 & Kuril Islands & $\begin{array}{l}\text { November } \\
15,2006\end{array}$ & $\begin{array}{l}\text { MacInnes and others, } \\
\text { 2009a }\end{array}$ \\
\hline $\begin{array}{l}\text { Sarychevo, Kuril } \\
\text { Islands, Russia }\end{array}$ & 48.083 & 153.266 & Kuril Islands & $\begin{array}{l}\text { November } \\
15,2006\end{array}$ & $\begin{array}{l}\text { MacInnes and others, } \\
\text { 2009a }\end{array}$ \\
\hline $\begin{array}{l}\text { NE Rasshua, Kuril } \\
\text { Islands, Russia }\end{array}$ & 47.795 & 153.050 & Kuril Islands & $\begin{array}{l}\text { November } \\
15,2006\end{array}$ & $\begin{array}{l}\text { MacInnes and others, } \\
\text { 2009a }\end{array}$ \\
\hline $\begin{array}{l}\text { Dushnaya Bay, Kuril } \\
\text { Islands, Russia }\end{array}$ & 47.07971 & 152.21016 & Kuril Islands & $\begin{array}{l}\text { November } \\
15,2006\end{array}$ & $\begin{array}{l}\text { MacInnes and others, } \\
2009 b\end{array}$ \\
\hline
\end{tabular}




\begin{tabular}{|c|c|c|c|c|c|}
\hline Site & $\begin{array}{l}\text { Latitude } \\
\text { (decimal } \\
\text { degrees) }\end{array}$ & $\begin{array}{c}\text { Longitude } \\
\text { (decimal } \\
\text { degrees) }\end{array}$ & $\begin{array}{c}\text { Name/designation of } \\
\text { tsunami }\end{array}$ & $\begin{array}{l}\text { Date of } \\
\text { tsunami }\end{array}$ & Reference \\
\hline $\begin{array}{l}\text { Dushnaya Bay, Kuril } \\
\text { Islands, Russia }\end{array}$ & 47.07880 & 152.20884 & Kuril Islands & $\begin{array}{l}\text { November } \\
15,2006\end{array}$ & $\begin{array}{l}\text { MacInnes and others, } \\
2009 \mathrm{~b}\end{array}$ \\
\hline $\begin{array}{l}\text { Dushnaya Bay, Kuril } \\
\text { Islands, Russia }\end{array}$ & 47.07835 & 152.20566 & Kuril Islands & $\begin{array}{l}\text { November } \\
15,2006 ; \\
\text { January } 13 \text {, } \\
2007\end{array}$ & $\begin{array}{l}\text { MacInnes and others, } \\
2009 \mathrm{~b}\end{array}$ \\
\hline $\begin{array}{l}\text { Dushnaya Bay, Kuril } \\
\text { Islands, Russia }\end{array}$ & 47.07809 & 152.19888 & Kuril Islands & $\begin{array}{l}\text { November } \\
15,2006 ; \\
\text { January } 13 \text {, } \\
2007\end{array}$ & $\begin{array}{l}\text { MacInnes and others, } \\
2009 b\end{array}$ \\
\hline $\begin{array}{l}\text { Dushnaya Bay, Kuril } \\
\text { Islands, Russia }\end{array}$ & 47.07754 & 152.19528 & Kuril Islands & $\begin{array}{l}\text { November } \\
15,2006\end{array}$ & $\begin{array}{l}\text { MacInnes and others, } \\
\text { 2009b }\end{array}$ \\
\hline $\begin{array}{l}\text { Dushnaya Bay, Kuril } \\
\text { Islands, Russia }\end{array}$ & 47.07537 & 152.19476 & Kuril Islands & $\begin{array}{l}\text { November } \\
15,2006 ; \\
\text { January } 13 \text {, } \\
2007\end{array}$ & $\begin{array}{l}\text { MacInnes and others, } \\
2009 \mathrm{~b}\end{array}$ \\
\hline $\begin{array}{l}\text { Dushnaya Bay, Kuril } \\
\text { Islands, Russia }\end{array}$ & 47.07124 & 152.19088 & Kuril Islands & $\begin{array}{l}\text { November } \\
15,2006\end{array}$ & $\begin{array}{l}\text { MacInnes and others, } \\
2009 \mathrm{~b}\end{array}$ \\
\hline $\begin{array}{l}\text { Dushnaya Bay, Kuril } \\
\text { Islands, Russia }\end{array}$ & 47.07039 & 152.18792 & Kuril Islands & $\begin{array}{l}\text { November } \\
15,2006\end{array}$ & $\begin{array}{l}\text { MacInnes and others, } \\
2009 \mathrm{~b}\end{array}$ \\
\hline $\begin{array}{l}\text { Dushnaya Bay, Kuril } \\
\text { Islands, Russia }\end{array}$ & 47.06971 & 152.18614 & Kuril Islands & $\begin{array}{l}\text { November } \\
15,2006 ; \\
\text { January } 13 \text {, } \\
2007\end{array}$ & $\begin{array}{l}\text { MacInnes and others, } \\
2009 \mathrm{~b}\end{array}$ \\
\hline $\begin{array}{l}\text { Dushnaya Bay, Kuril } \\
\text { Islands, Russia }\end{array}$ & 47.06960 & 152.18429 & Kuril Islands & $\begin{array}{l}\text { November } \\
15,2006 ; \\
\text { January } 13 \text {, } \\
2007\end{array}$ & $\begin{array}{l}\text { MacInnes and others, } \\
2009 \mathrm{~b}\end{array}$ \\
\hline $\begin{array}{l}\text { Dushnaya Bay, Kuril } \\
\text { Islands, Russia }\end{array}$ & 47.06393 & 152.17726 & Kuril Islands & $\begin{array}{l}\text { November } \\
15,2006 ; \\
\text { January } 13 \text {, } \\
2007\end{array}$ & $\begin{array}{l}\text { MacInnes and others, } \\
2009 b\end{array}$ \\
\hline $\begin{array}{l}\text { Dushnaya Bay, Kuril } \\
\text { Islands, Russia }\end{array}$ & 47.06201 & 152.17549 & Kuril Islands & $\begin{array}{l}\text { November } \\
15,2006 ; \\
\text { January } 13 \text {, } \\
2007\end{array}$ & $\begin{array}{l}\text { MacInnes and others, } \\
2009 \mathrm{~b}\end{array}$ \\
\hline $\begin{array}{l}\text { Dushnaya Bay, Kuril } \\
\text { Islands, Russia }\end{array}$ & 47.06094 & 152.17313 & Kuril Islands & $\begin{array}{l}\text { November } \\
15,2006\end{array}$ & $\begin{array}{l}\text { MacInnes and others, } \\
2009 \mathrm{~b}\end{array}$ \\
\hline $\begin{array}{l}\text { Dushnaya Bay, Kuril } \\
\text { Islands, Russia }\end{array}$ & 47.05807 & 152.16878 & Kuril Islands & $\begin{array}{l}\text { November } \\
15,2006 ; \\
\text { January } 13 \text {, } \\
2007\end{array}$ & $\begin{array}{l}\text { MacInnes and others, } \\
2009 \mathrm{~b}\end{array}$ \\
\hline $\begin{array}{l}\text { Dushnaya Bay, Kuril } \\
\text { Islands, Russia }\end{array}$ & 47.05628 & 152.16650 & Kuril Islands & $\begin{array}{l}\text { November } \\
15,2006 ; \\
\text { January } 13 \text {, } \\
2007\end{array}$ & $\begin{array}{l}\text { MacInnes and others, } \\
2009 \mathrm{~b}\end{array}$ \\
\hline $\begin{array}{l}\text { Dushnaya Bay, Kuril } \\
\text { Islands, Russia }\end{array}$ & 47.04530 & 152.15915 & Kuril Islands & $\begin{array}{l}\text { November } \\
15,2006\end{array}$ & $\begin{array}{l}\text { MacInnes and others, } \\
2009 \mathrm{~b}\end{array}$ \\
\hline $\begin{array}{l}\text { Yankicha, Kuril } \\
\text { Islands, Russia }\end{array}$ & 47.52596 & 152.82620 & Kuril Islands & $\begin{array}{l}\text { November } \\
15,2006\end{array}$ & $\begin{array}{l}\text { MacInnes and others, } \\
2009 \mathrm{~b}\end{array}$ \\
\hline $\begin{array}{l}\text { Sarychevo, Kuril } \\
\text { Islands, Russia }\end{array}$ & 48.08416 & 153.26740 & Kuril Islands & $\begin{array}{l}\text { November } \\
15,2006\end{array}$ & $\begin{array}{l}\text { MacInnes and others, } \\
2009 \mathrm{~b}\end{array}$ \\
\hline
\end{tabular}




\begin{tabular}{|c|c|c|c|c|c|}
\hline Site & $\begin{array}{l}\text { Latitude } \\
\text { (decimal } \\
\text { degrees) }\end{array}$ & $\begin{array}{c}\text { Longitude } \\
\text { (decimal } \\
\text { degrees) }\end{array}$ & $\begin{array}{c}\text { Name/designation of } \\
\text { tsunami }\end{array}$ & $\begin{array}{l}\text { Date of } \\
\text { tsunami }\end{array}$ & Reference \\
\hline $\begin{array}{l}\text { Sarychevo, Kuril } \\
\text { Islands, Russia }\end{array}$ & 48.08323 & 153.26612 & Kuril Islands & $\begin{array}{l}\text { November } \\
15,2006\end{array}$ & $\begin{array}{l}\text { MacInnes and others, } \\
2009 \mathrm{~b}\end{array}$ \\
\hline $\begin{array}{l}\text { Sarychevo, Kuril } \\
\text { Islands, Russia }\end{array}$ & 48.07906 & 153.26357 & Kuril Islands & $\begin{array}{l}\text { November } \\
15,2006\end{array}$ & $\begin{array}{l}\text { MacInnes and others, } \\
2009 \mathrm{~b}\end{array}$ \\
\hline $\begin{array}{l}\text { Sarychevo, Kuril } \\
\text { Islands, Russia }\end{array}$ & 48.07510 & 153.26518 & Kuril Islands & $\begin{array}{l}\text { November } \\
15,2006 \\
\end{array}$ & $\begin{array}{l}\text { MacInnes and others, } \\
2009 \mathrm{~b}\end{array}$ \\
\hline $\begin{array}{l}\text { Sarychevo, Kuril } \\
\text { Islands, Russia }\end{array}$ & 48.07340 & 153.26681 & Kuril Islands & $\begin{array}{l}\text { November } \\
15,2006\end{array}$ & $\begin{array}{l}\text { MacInnes and others, } \\
2009 \mathrm{~b}\end{array}$ \\
\hline $\begin{array}{l}\text { Sarychevo, Kuril } \\
\text { Islands, Russia }\end{array}$ & 48.06642 & 153.26921 & Kuril Islands & $\begin{array}{l}\text { November } \\
15,2006 ; \\
\text { January 13, } \\
2007\end{array}$ & $\begin{array}{l}\text { MacInnes and others, } \\
\text { 2009b }\end{array}$ \\
\hline $\begin{array}{l}\text { South Bay, Kuril } \\
\text { Islands, Russia }\end{array}$ & 48.04199 & 153.24922 & Kuril Islands & $\begin{array}{l}\text { November } \\
15,2006\end{array}$ & $\begin{array}{l}\text { MacInnes and others, } \\
2009 \mathrm{~b}\end{array}$ \\
\hline $\begin{array}{l}\text { Ainu Bay, Kuril } \\
\text { Islands, Russia }\end{array}$ & 48.04412 & 153.22497 & Kuril Islands & $\begin{array}{l}\text { November } \\
15,2006 ; \\
\text { January 13, } \\
2007\end{array}$ & $\begin{array}{l}\text { MacInnes and others, } \\
2009 \mathrm{~b}\end{array}$ \\
\hline $\begin{array}{l}\text { Ainu Bay, Kuril } \\
\text { Islands, Russia }\end{array}$ & 48.04269 & 153.22650 & Kuril Islands & $\begin{array}{l}\text { November } \\
15,2006 ; \\
\text { January } 13 \text {, } \\
2007\end{array}$ & $\begin{array}{l}\text { MacInnes and others, } \\
2009 \mathrm{~b}\end{array}$ \\
\hline $\begin{array}{l}\text { Pasir Putih, } \\
\text { Pangandaran Peninsula } \\
\text { National Park, and } \\
\text { other locations on } \\
\text { southern coast of } \\
\text { central Java, including } \\
\text { island of Nusa } \\
\text { Kambangan, Java, } \\
\text { Indonesia }\end{array}$ & -7.732 & 108.883 & Java & $\begin{array}{l}\text { July } 17, \\
2006\end{array}$ & Fritz and others, 2007 \\
\hline $\begin{array}{l}\text { Lagundri Bay, Nias, } \\
\text { Sumatra, Indonesia }\end{array}$ & 0.578 & 97.732 & Sumatra & $\begin{array}{l}\text { March 28, } \\
2005\end{array}$ & $\begin{array}{l}\text { Peters, unpublished } \\
\text { data }\end{array}$ \\
\hline Bang More, Thailand & 8.881 & 98.270 & Indian Ocean & $\begin{array}{l}\text { December } \\
26,2004\end{array}$ & $\begin{array}{l}\text { Kokocinski and } \\
\text { others, } 2009\end{array}$ \\
\hline $\begin{array}{l}\text { Pakarang Cape, } \\
\text { Thailand }\end{array}$ & 8.737 & 98.222 & Indian Ocean & $\begin{array}{l}\text { December } \\
26,2004\end{array}$ & $\begin{array}{l}\text { Kokocinski and } \\
\text { others, } 2009\end{array}$ \\
\hline Patong, Thailand & 7.893 & 98.295 & Indian Ocean & $\begin{array}{l}\text { December } \\
26,2004\end{array}$ & $\begin{array}{l}\text { Kokocinski and } \\
\text { others, } 2009\end{array}$ \\
\hline Tri Trang, Thailand & 7.886 & 98.277 & Indian Ocean & $\begin{array}{l}\text { December } \\
26,2004\end{array}$ & $\begin{array}{l}\text { Kokocinski and } \\
\text { others, } 2009\end{array}$ \\
\hline $\begin{array}{l}\text { Pakarang Cape, } \\
\text { Thailand }\end{array}$ & 8.737 & 98.222 & Indian Ocean & $\begin{array}{l}\text { December } \\
26,2004\end{array}$ & $\begin{array}{l}\text { Goto and others, } \\
2009\end{array}$ \\
\hline $\begin{array}{l}\text { Kho Khao Island, } \\
\text { Thailand }\end{array}$ & 8.958 & 98.300 & Indian Ocean & $\begin{array}{l}\text { December } \\
26,2004\end{array}$ & $\begin{array}{l}\text { Jagodziski and } \\
\text { others, } 2009\end{array}$ \\
\hline Nam Khem, Thailand & 8.857 & 98.275 & Indian Ocean & $\begin{array}{l}\text { December } \\
26,2004\end{array}$ & $\begin{array}{l}\text { Kozak and Siepak, } \\
2009\end{array}$ \\
\hline Thung Tuk, Thailand & 8.885 & 98.268 & Indian Ocean & $\begin{array}{l}\text { December } \\
26,2004\end{array}$ & $\begin{array}{l}\text { Kozak and Siepak, } \\
2009\end{array}$ \\
\hline Patong, Thailand & 7.893 & 98.295 & Indian Ocean & $\begin{array}{l}\text { December } \\
26,2004\end{array}$ & $\begin{array}{l}\text { Kozak and Siepak, } \\
2009\end{array}$ \\
\hline
\end{tabular}




\begin{tabular}{|c|c|c|c|c|c|}
\hline Site & $\begin{array}{l}\text { Latitude } \\
\text { (decimal } \\
\text { degrees) }\end{array}$ & $\begin{array}{c}\text { Longitude } \\
\text { (decimal } \\
\text { degrees) }\end{array}$ & $\begin{array}{c}\text { Name/designation of } \\
\text { tsunami }\end{array}$ & $\begin{array}{l}\text { Date of } \\
\text { tsunami }\end{array}$ & Reference \\
\hline $\begin{array}{l}\text { Lhok Nga, Sumatra, } \\
\text { Indonesia }\end{array}$ & 5.485 & 95.238 & Indian Ocean & $\begin{array}{l}\text { December } \\
26,2004\end{array}$ & $\begin{array}{l}\text { Paris and others, } \\
2009\end{array}$ \\
\hline $\begin{array}{l}\text { Chennai, Tamil Nadu, } \\
\text { India }\end{array}$ & 13.020 & 80.250 & Indian Ocean & $\begin{array}{l}\text { December } \\
26,2004\end{array}$ & $\begin{array}{l}\text { Srinivasalu and } \\
\text { others, } 2009\end{array}$ \\
\hline $\begin{array}{l}\text { Cooum River mouth, } \\
\text { Tamil Nadu, India }\end{array}$ & 13.067 & 80.288 & Indian Ocean & $\begin{array}{l}\text { December } \\
26,2004\end{array}$ & $\begin{array}{l}\text { Srinivasalu and } \\
\text { others, } 2009\end{array}$ \\
\hline $\begin{array}{l}\text { Injambakkam, Tamil } \\
\text { Nadu, India }\end{array}$ & 12.915 & 80.257 & Indian Ocean & $\begin{array}{l}\text { December } \\
26,2004\end{array}$ & $\begin{array}{l}\text { Srinivasalu and } \\
\text { others, } 2009\end{array}$ \\
\hline $\begin{array}{l}\text { Kadalore,Tamil Nadu, } \\
\text { India }\end{array}$ & 11.744 & 79.787 & Indian Ocean & $\begin{array}{l}\text { December } \\
26,2004\end{array}$ & $\begin{array}{l}\text { Srinivasalu and } \\
\text { others, } 2009\end{array}$ \\
\hline $\begin{array}{l}\text { Mudasal Odai, Tamil } \\
\text { Nadu, India }\end{array}$ & 11.445 & 79.776 & Indian Ocean & $\begin{array}{l}\text { December } \\
26,2004\end{array}$ & $\begin{array}{l}\text { Srinivasalu and } \\
\text { others, } 2009\end{array}$ \\
\hline $\begin{array}{l}\text { Velankanni, Tamil } \\
\text { Nadu, India }\end{array}$ & 10.681 & 79.853 & Indian Ocean & $\begin{array}{l}\text { December } \\
26,2004\end{array}$ & $\begin{array}{l}\text { Srinivasalu and } \\
\text { others, } 2009\end{array}$ \\
\hline $\begin{array}{l}\text { Vedharanyam, Tamil } \\
\text { Nadu, India }\end{array}$ & 10.373 & 79.868 & Indian Ocean & $\begin{array}{l}\text { December } \\
26,2004\end{array}$ & $\begin{array}{l}\text { Srinivasalu and } \\
\text { others, } 2009\end{array}$ \\
\hline $\begin{array}{l}\text { Ao Kheuy beach, } \\
\text { Thailand }\end{array}$ & 9.316 & 98.381 & Indian Ocean & $\begin{array}{l}\text { December } \\
26,2004\end{array}$ & $\begin{array}{l}\text { Srisutam and } \\
\text { Wagner, } 2009\end{array}$ \\
\hline $\begin{array}{l}\text { Khuk Khak beach, } \\
\text { Thailand }\end{array}$ & 8.696 & 98.239 & Indian Ocean & $\begin{array}{l}\text { December } \\
26,2004\end{array}$ & $\begin{array}{l}\text { Srisutam and } \\
\text { Wagner, } 2009\end{array}$ \\
\hline $\begin{array}{l}\text { Thap Lamu Navy } \\
\text { Base, Thailand }\end{array}$ & 8.566 & 98.221 & Indian Ocean & $\begin{array}{l}\text { December } \\
26,2004\end{array}$ & $\begin{array}{l}\text { Yawsangratt and } \\
\text { others, } 2009\end{array}$ \\
\hline $\begin{array}{l}\text { Bang Tao Beach, } \\
\text { Thailand }\end{array}$ & 7.989 & 98.294 & Indian Ocean & $\begin{array}{l}\text { December } \\
26,2004\end{array}$ & $\begin{array}{l}\text { Choowong and } \\
\text { others, } 2008\end{array}$ \\
\hline $\begin{array}{l}\text { Hambantota, Karagan } \\
\text { Lagoon, Sri Lanka }\end{array}$ & 6.132 & 81.124 & Indian Ocean & $\begin{array}{l}\text { December } \\
26,2004\end{array}$ & Jackson, 2008 \\
\hline $\begin{array}{l}\text { Helawe Lagoon, Sri } \\
\text { Lanka }\end{array}$ & 6.672 & 81.761 & Indian Ocean & $\begin{array}{l}\text { December } \\
26,2004\end{array}$ & Jackson, 2008 \\
\hline Bang Sak, Thailand & 9.700 & 97.000 & Indian Ocean & $\begin{array}{l}\text { December } \\
26,2004\end{array}$ & $\begin{array}{l}\text { Matsumoto and } \\
\text { others, } 2008\end{array}$ \\
\hline $\begin{array}{l}\text { Meulaboh, Aceh, } \\
\text { Sumatra, Indonesia }\end{array}$ & 4.136 & 96.125 & Indian Ocean & $\begin{array}{l}\text { December } \\
26,2004\end{array}$ & $\begin{array}{l}\text { Monecke and others, } \\
2008\end{array}$ \\
\hline Yala, Sri Lanka & 6.279 & 81.425 & Indian Ocean & $\begin{array}{l}\text { December } \\
26,2004\end{array}$ & $\begin{array}{l}\text { Morton and others, } \\
2008\end{array}$ \\
\hline $\begin{array}{l}\text { Madhirivaadhoo, } \\
\text { South Maalhosmadulu } \\
\text { (Baa) Atoll, Maldives }\end{array}$ & 5.133 & 72.950 & Indian Ocean & $\begin{array}{l}\text { December } \\
26,2004\end{array}$ & $\begin{array}{l}\text { Nichol and Kench, } \\
2008\end{array}$ \\
\hline $\begin{array}{l}\text { Thiladhoo, South } \\
\text { Maalhosmadulu (Baa) } \\
\text { Atoll, Maldives }\end{array}$ & 5.133 & 72.950 & Indian Ocean & $\begin{array}{l}\text { December } \\
26,2004\end{array}$ & $\begin{array}{l}\text { Nichol and Kench, } \\
2008\end{array}$ \\
\hline $\begin{array}{l}\text { Milaidhoo, South } \\
\text { Maalhosmadulu (Baa) } \\
\text { Atoll, Maldives }\end{array}$ & 5.133 & 72.950 & Indian Ocean & $\begin{array}{l}\text { December } \\
26,2004\end{array}$ & $\begin{array}{l}\text { Nichol and Kench, } \\
2008\end{array}$ \\
\hline $\begin{array}{l}\text { Hulhudhoo, South } \\
\text { Maalhosmadulu (Baa) } \\
\text { Atoll, Maldives }\end{array}$ & 5.133 & 72.950 & Indian Ocean & $\begin{array}{l}\text { December } \\
26,2004\end{array}$ & $\begin{array}{l}\text { Nichol and Kench, } \\
2008\end{array}$ \\
\hline $\begin{array}{l}\text { Dhakandhoo, South } \\
\text { Maalhosmadulu (Baa) } \\
\text { Atoll, Maldives }\end{array}$ & 5.133 & 72.950 & Indian Ocean & $\begin{array}{l}\text { December } \\
26,2004\end{array}$ & $\begin{array}{l}\text { Nichol and Kench, } \\
2008\end{array}$ \\
\hline Tamil Nadu, India & 12.000 & 79.900 & Indian Ocean & $\begin{array}{l}\text { December } \\
26,2004\end{array}$ & $\begin{array}{l}\text { Bahlburg and Weiss, } \\
2007\end{array}$ \\
\hline
\end{tabular}




\begin{tabular}{|c|c|c|c|c|c|}
\hline Site & $\begin{array}{l}\text { Latitude } \\
\text { (decimal } \\
\text { degrees) }\end{array}$ & $\begin{array}{c}\text { Longitude } \\
\text { (decimal } \\
\text { degrees) }\end{array}$ & $\begin{array}{c}\text { Name/designation of } \\
\text { tsunami }\end{array}$ & $\begin{array}{l}\text { Date of } \\
\text { tsunami }\end{array}$ & Reference \\
\hline $\begin{array}{l}\text { between Malindi and } \\
\text { Lamu, Kenya }\end{array}$ & -3.000 & 40.150 & Indian Ocean & $\begin{array}{l}\text { December } \\
26,2004\end{array}$ & $\begin{array}{l}\text { Bahlburg and Weiss, } \\
2007\end{array}$ \\
\hline $\begin{array}{l}\text { Bang Tao Beach, } \\
\text { Thailand }\end{array}$ & 7.989 & 98.294 & Indian Ocean & $\begin{array}{l}\text { December } \\
26,2004\end{array}$ & $\begin{array}{l}\text { Choowong and } \\
\text { others, } 2007\end{array}$ \\
\hline $\begin{array}{l}\text { Karon Beach, } \\
\text { Thailand }\end{array}$ & 7.849 & 98.295 & Indian Ocean & $\begin{array}{l}\text { December } \\
26,2004\end{array}$ & $\begin{array}{l}\text { Choowong and } \\
\text { others, } 2007\end{array}$ \\
\hline $\begin{array}{l}\text { Ban Khuek Khak, } \\
\text { Thailand }\end{array}$ & 8.690 & 98.270 & Indian Ocean & $\begin{array}{l}\text { December } \\
26,2004\end{array}$ & $\begin{array}{l}\text { Choowong and } \\
\text { others, } 2007\end{array}$ \\
\hline $\begin{array}{l}\text { Khuk Khak Beach, } \\
\text { Thailand }\end{array}$ & 8.694 & 98.238 & Indian Ocean & $\begin{array}{l}\text { December } \\
26,2004\end{array}$ & $\begin{array}{l}\text { Hawkes and others, } \\
2007\end{array}$ \\
\hline Koh Phi Phi, Thailand & 7.743 & 98.776 & Indian Ocean & $\begin{array}{l}\text { December } \\
26,2004\end{array}$ & $\begin{array}{l}\text { Hawkes and others, } \\
2007\end{array}$ \\
\hline Koh Lanta, Thailand & 7.655 & 99.041 & Indian Ocean & $\begin{array}{l}\text { December } \\
26,2004\end{array}$ & $\begin{array}{l}\text { Hawkes and others, } \\
2007\end{array}$ \\
\hline $\begin{array}{l}\text { Kuala Teriang, } \\
\text { Malaysia }\end{array}$ & 6.335 & 99.734 & Indian Ocean & $\begin{array}{l}\text { December } \\
26,2004\end{array}$ & $\begin{array}{l}\text { Hawkes and others, } \\
2007\end{array}$ \\
\hline Langkawi, Malaysia & 6.323 & 99.855 & Indian Ocean & $\begin{array}{l}\text { December } \\
26,2004\end{array}$ & $\begin{array}{l}\text { Hawkes and others, } \\
2007\end{array}$ \\
\hline $\begin{array}{l}\text { Sungai Burong, Pulau } \\
\text { Penang, Malaysia }\end{array}$ & 5.340 & 100.196 & Indian Ocean & $\begin{array}{l}\text { December } \\
26,2004\end{array}$ & $\begin{array}{l}\text { Hawkes and others, } \\
2007\end{array}$ \\
\hline Nam Khem, Thailand & 8.839 & 98.267 & Indian Ocean & $\begin{array}{l}\text { December } \\
26,2004\end{array}$ & Hori and others, 2007 \\
\hline Khao Lak, Thailand & 8.681 & 98.240 & Indian Ocean & $\begin{array}{l}\text { December } \\
26,2004\end{array}$ & Hori and others, 2007 \\
\hline $\begin{array}{l}\text { Phuket Island, Khao } \\
\text { Lak region including } \\
\text { some Similan Islands, } \\
\text { Thailand }\end{array}$ & 8.642 & 97.636 & Indian Ocean & $\begin{array}{l}\text { December } \\
26,2004\end{array}$ & $\begin{array}{l}\text { Kelletat and others, } \\
2007\end{array}$ \\
\hline $\begin{array}{l}\text { Phi Don Islands, } \\
\text { Thailand }\end{array}$ & 7.743 & 98.775 & Indian Ocean & $\begin{array}{l}\text { December } \\
26,2004\end{array}$ & $\begin{array}{l}\text { Kelletat and others, } \\
2007\end{array}$ \\
\hline $\begin{array}{l}\text { South Maalhosmadulu } \\
\text { atoll, Maldives }\end{array}$ & 5.199 & 72.999 & Indian Ocean & $\begin{array}{l}\text { December } \\
26,2004\end{array}$ & $\begin{array}{l}\text { Kench and others, } \\
2007\end{array}$ \\
\hline $\begin{array}{l}\text { Kerala coast, } \\
\text { Kayamkulam Estuary, } \\
\text { India }\end{array}$ & 9.118 & 76.472 & Indian Ocean & $\begin{array}{l}\text { December } \\
26,2004\end{array}$ & $\begin{array}{l}\text { Narayana and others, } \\
2007\end{array}$ \\
\hline Patong Bay, Thailand & 7.885 & 98.27405 & Indian Ocean & $\begin{array}{l}\text { December } \\
26,2004\end{array}$ & $\begin{array}{l}\text { Szczucinski and } \\
\text { others, } 2007\end{array}$ \\
\hline Patong Bay, Thailand & 7.88357 & 98.27392 & Indian Ocean & $\begin{array}{l}\text { December } \\
26,2004\end{array}$ & $\begin{array}{l}\text { Szczucinski and } \\
\text { others, } 2007\end{array}$ \\
\hline Patong, Thailand & 7.88207 & 98.28848 & Indian Ocean & $\begin{array}{l}\text { December } \\
26,2004\end{array}$ & $\begin{array}{l}\text { Szczucinski and } \\
\text { others, } 2007\end{array}$ \\
\hline Patong, Thailand & 7.8818 & 98.28867 & Indian Ocean & $\begin{array}{l}\text { December } \\
26,2004\end{array}$ & $\begin{array}{l}\text { Szczucinski and } \\
\text { others, } 2007\end{array}$ \\
\hline Patong, Thailand & 7.88145 & 98.28880 & Indian Ocean & $\begin{array}{l}\text { December } \\
26,2004\end{array}$ & $\begin{array}{l}\text { Szczucinski and } \\
\text { others, } 2007\end{array}$ \\
\hline Patong, Thailand & 7.88107 & 98.28915 & Indian Ocean & $\begin{array}{l}\text { December } \\
26,2004\end{array}$ & $\begin{array}{l}\text { Szczucinski and } \\
\text { others, } 2007\end{array}$ \\
\hline Patong, Thailand & 7.88255 & 98.28880 & Indian Ocean & $\begin{array}{l}\text { December } \\
26,2004\end{array}$ & $\begin{array}{l}\text { Szczucinski and } \\
\text { others, } 2007\end{array}$ \\
\hline Patong, Thailand & 7.88230 & 98.28893 & Indian Ocean & $\begin{array}{l}\text { December } \\
26,2004\end{array}$ & $\begin{array}{l}\text { Szczucinski and } \\
\text { others, } 2007\end{array}$ \\
\hline
\end{tabular}




\begin{tabular}{|c|c|c|c|c|c|}
\hline Site & $\begin{array}{l}\text { Latitude } \\
\text { (decimal } \\
\text { degrees) }\end{array}$ & $\begin{array}{c}\text { Longitude } \\
\text { (decimal } \\
\text { degrees) }\end{array}$ & $\begin{array}{c}\text { Name/designation of } \\
\text { tsunami }\end{array}$ & $\begin{array}{l}\text { Date of } \\
\text { tsunami }\end{array}$ & Reference \\
\hline Nam Khem, Thailand & 8.8578 & 98.26550 & Indian Ocean & $\begin{array}{l}\text { December } \\
26,2004\end{array}$ & $\begin{array}{l}\text { Szczucinski and } \\
\text { others, } 2007\end{array}$ \\
\hline Nam Khem, Thailand & 8.85695 & 98.26588 & Indian Ocean & $\begin{array}{l}\text { December } \\
26,2004\end{array}$ & $\begin{array}{l}\text { Szczucinski and } \\
\text { others, } 2007\end{array}$ \\
\hline Nam Khem, Thailand & 8.85675 & 98.27183 & Indian Ocean & $\begin{array}{l}\text { December } \\
26,2004\end{array}$ & $\begin{array}{l}\text { Szczucinski and } \\
\text { others, } 2007\end{array}$ \\
\hline Nam Khem, Thailand & 8.85922 & 98.26567 & Indian Ocean & $\begin{array}{l}\text { December } \\
26,2004\end{array}$ & $\begin{array}{l}\text { Szczucinski and } \\
\text { others, } 2007\end{array}$ \\
\hline Nam Khem, Thailand & 8.86030 & 98.27545 & Indian Ocean & $\begin{array}{l}\text { December } \\
26,2004\end{array}$ & $\begin{array}{l}\text { Szczucinski and } \\
\text { others, } 2007\end{array}$ \\
\hline Bang Mor, Thailand & 8.83288 & 98.26880 & Indian Ocean & $\begin{array}{l}\text { December } \\
26,2004\end{array}$ & $\begin{array}{l}\text { Szczucinski and } \\
\text { others, } 2007\end{array}$ \\
\hline Bang Mor, Thailand & 8.83178 & 98.27118 & Indian Ocean & $\begin{array}{l}\text { December } \\
26,2004\end{array}$ & $\begin{array}{l}\text { Szczucinski and } \\
\text { others, } 2007\end{array}$ \\
\hline $\begin{array}{l}\text { Banda Aceh coastal } \\
\text { plain, Sumatra, } \\
\text { Indonesia }\end{array}$ & 5.600 & 93.350 & Indian Ocean & $\begin{array}{l}\text { December } \\
26,2004\end{array}$ & $\begin{array}{l}\text { Umitsu and others, } \\
2007\end{array}$ \\
\hline $\begin{array}{l}\text { Nam Khem coastal } \\
\text { plain, Thailand }\end{array}$ & 8.856 & 98.271 & Indian Ocean & $\begin{array}{l}\text { December } \\
26,2004\end{array}$ & $\begin{array}{l}\text { Umitsu and others, } \\
2007\end{array}$ \\
\hline Yala, Sri Lanka & 6.166 & 81.255 & Indian Ocean & $\begin{array}{l}\text { December } \\
26,2004\end{array}$ & Goff and others, 2006 \\
\hline Boosa, Sri Lanka & 6.048 & 80.090 & Indian Ocean & $\begin{array}{l}\text { December } \\
26,2004\end{array}$ & Goff and others, 2006 \\
\hline Telwatte, Sri Lanka & 6.111 & 80.043 & Indian Ocean & $\begin{array}{l}\text { December } \\
26,2004\end{array}$ & Goff and others, 2006 \\
\hline Wellawatta, Sri Lanka & 6.526 & 79.514 & Indian Ocean & $\begin{array}{l}\text { December } \\
26,2004\end{array}$ & Goff and others, 2006 \\
\hline $\begin{array}{l}\text { Katukurunda, Sri } \\
\text { Lanka }\end{array}$ & 6.334 & 79.577 & Indian Ocean & $\begin{array}{l}\text { December } \\
26,2004\end{array}$ & Goff and others, 2006 \\
\hline $\begin{array}{l}\text { Nalaveli Hotel, Sri } \\
\text { Lanka }\end{array}$ & 8.707 & 81.188 & Indian Ocean & $\begin{array}{l}\text { December } \\
26,2004\end{array}$ & Goff and others, 2006 \\
\hline Mankeri, Sri Lanka & 8.014 & 81.490 & Indian Ocean & $\begin{array}{l}\text { December } \\
26,2004\end{array}$ & Goff and others, 2006 \\
\hline $\begin{array}{l}\text { Kalmunai Kuddi, Sri } \\
\text { Lanka }\end{array}$ & 7.405 & 81.842 & Indian Ocean & $\begin{array}{l}\text { December } \\
26,2004\end{array}$ & Goff and others, 2006 \\
\hline $\begin{array}{l}\text { Kalmunai Kuddi, Sri } \\
\text { Lanka }\end{array}$ & 7.423 & 81.830 & Indian Ocean & $\begin{array}{l}\text { December } \\
26,2004\end{array}$ & Goff and others, 2006 \\
\hline Tangalla, Sri Lanka & 6.012 & 80.477 & Indian Ocean & $\begin{array}{l}\text { December } \\
26,2004\end{array}$ & Goff and others, 2006 \\
\hline Hikkaduwa, Sri Lanka & 6.077 & 80.062 & Indian Ocean & $\begin{array}{l}\text { December } \\
26,2004\end{array}$ & Goff and others, 2006 \\
\hline $\begin{array}{l}\text { Jantang, Sumatra, } \\
\text { Indonesia }\end{array}$ & 5.279 & 95.247 & Indian Ocean & $\begin{array}{l}\text { December } \\
26,2004\end{array}$ & $\begin{array}{l}\text { Jaffe and others, } \\
2006\end{array}$ \\
\hline $\begin{array}{l}\text { Jantang, Sumatra, } \\
\text { Indonesia }\end{array}$ & 5.280 & 95.247 & Indian Ocean & $\begin{array}{l}\text { December } \\
26,2004 \\
\end{array}$ & $\begin{array}{l}\text { Jaffe and others, } \\
2006\end{array}$ \\
\hline $\begin{array}{l}\text { Jantang, Sumatra, } \\
\text { Indonesia }\end{array}$ & 5.276 & 95.250 & Indian Ocean & $\begin{array}{l}\text { December } \\
26,2004\end{array}$ & $\begin{array}{l}\text { Jaffe and others, } \\
2006\end{array}$ \\
\hline $\begin{array}{l}\text { Jantang, Sumatra, } \\
\text { Indonesia }\end{array}$ & 5.276 & 95.250 & Indian Ocean & $\begin{array}{l}\text { December } \\
26,2004\end{array}$ & $\begin{array}{l}\text { Jaffe and others, } \\
2006\end{array}$ \\
\hline $\begin{array}{l}\text { Jantang, Sumatra, } \\
\text { Indonesia }\end{array}$ & 5.276 & 95.251 & Indian Ocean & $\begin{array}{l}\text { December } \\
26,2004\end{array}$ & $\begin{array}{l}\text { Jaffe and others, } \\
2006\end{array}$ \\
\hline
\end{tabular}




\begin{tabular}{|c|c|c|c|c|c|}
\hline Site & $\begin{array}{l}\text { Latitude } \\
\text { (decimal } \\
\text { degrees) } \\
\end{array}$ & $\begin{array}{c}\text { Longitude } \\
\text { (decimal } \\
\text { degrees) }\end{array}$ & $\begin{array}{l}\text { Name/designation of } \\
\text { tsunami }\end{array}$ & $\begin{array}{l}\text { Date of } \\
\text { tsunami }\end{array}$ & Reference \\
\hline $\begin{array}{l}\text { Lhokkruet, Sumatra, } \\
\text { Indonesia }\end{array}$ & 4.896 & 95.403 & Indian Ocean & $\begin{array}{l}\text { December } \\
26,2004\end{array}$ & $\begin{array}{l}\text { Jaffe and others, } \\
2006\end{array}$ \\
\hline $\begin{array}{l}\text { Lhokkruet, Sumatra, } \\
\text { Indonesia }\end{array}$ & 4.897 & 95.404 & Indian Ocean & $\begin{array}{l}\text { December } \\
26,2004\end{array}$ & $\begin{array}{l}\text { Jaffe and others, } \\
2006\end{array}$ \\
\hline $\begin{array}{l}\text { Lhokkruet, Sumatra, } \\
\text { Indonesia }\end{array}$ & 4.897 & 95.404 & Indian Ocean & $\begin{array}{l}\text { December } \\
26,2004 \\
\end{array}$ & $\begin{array}{l}\text { Jaffe and others, } \\
2006\end{array}$ \\
\hline $\begin{array}{l}\text { Lhokkruet, Sumatra, } \\
\text { Indonesia }\end{array}$ & 4.898 & 95.404 & Indian Ocean & $\begin{array}{l}\text { December } \\
26,2004\end{array}$ & $\begin{array}{l}\text { Jaffe and others, } \\
2006\end{array}$ \\
\hline $\begin{array}{l}\text { Lhok Leupung, } \\
\text { Sumatra, Indonesia }\end{array}$ & 4.691 & 95.536 & Indian Ocean & $\begin{array}{l}\text { December } \\
26,2004\end{array}$ & $\begin{array}{l}\text { Jaffe and others, } \\
2006\end{array}$ \\
\hline $\begin{array}{l}\text { Lhok Leupung, } \\
\text { Sumatra, Indonesia }\end{array}$ & 4.691 & 95.536 & Indian Ocean & $\begin{array}{l}\text { December } \\
26,2004 \\
\end{array}$ & $\begin{array}{l}\text { Jaffe and others, } \\
2006\end{array}$ \\
\hline $\begin{array}{l}\text { Lhok Leupung, } \\
\text { Sumatra, Indonesia }\end{array}$ & 4.691 & 95.537 & Indian Ocean & $\begin{array}{l}\text { December } \\
26,2004\end{array}$ & $\begin{array}{l}\text { Jaffe and others, } \\
2006\end{array}$ \\
\hline $\begin{array}{l}\text { Lhok Leupung, } \\
\text { Sumatra, Indonesia }\end{array}$ & 4.692 & 95.537 & Indian Ocean & $\begin{array}{l}\text { December } \\
26,2004\end{array}$ & $\begin{array}{l}\text { Jaffe and others, } \\
2006\end{array}$ \\
\hline $\begin{array}{l}\text { Kuala Meurisi, } \\
\text { Sumatra, Indonesia }\end{array}$ & 4.613 & 95.624 & Indian Ocean & $\begin{array}{l}\text { December } \\
26,2004\end{array}$ & $\begin{array}{l}\text { Jaffe and others, } \\
2006\end{array}$ \\
\hline $\begin{array}{l}\text { Kuala Meurisi, } \\
\text { Sumatra, Indonesia }\end{array}$ & 4.613 & 95.625 & Indian Ocean & $\begin{array}{l}\text { December } \\
26,2004\end{array}$ & $\begin{array}{l}\text { Jaffe and others, } \\
2006\end{array}$ \\
\hline $\begin{array}{l}\text { Kuala Meurisi, } \\
\text { Sumatra, Indonesia }\end{array}$ & 4.614 & 95.625 & Indian Ocean & $\begin{array}{l}\text { December } \\
26,2004\end{array}$ & $\begin{array}{l}\text { Jaffe and others, } \\
2006\end{array}$ \\
\hline $\begin{array}{l}\text { Kuala Meurisi, } \\
\text { Sumatra, Indonesia }\end{array}$ & 4.614 & 95.625 & Indian Ocean & $\begin{array}{l}\text { December } \\
26,2004\end{array}$ & $\begin{array}{l}\text { Jaffe and others, } \\
2006\end{array}$ \\
\hline $\begin{array}{l}\text { Kuala Meurisi, } \\
\text { Sumatra, Indonesia }\end{array}$ & 4.616 & 95.627 & Indian Ocean & $\begin{array}{l}\text { December } \\
26,2004\end{array}$ & $\begin{array}{l}\text { Jaffe and others, } \\
2006\end{array}$ \\
\hline $\begin{array}{l}\text { Kuala Meurisi, } \\
\text { Sumatra, Indonesia }\end{array}$ & 4.616 & 95.628 & Indian Ocean & $\begin{array}{l}\text { December } \\
26,2004\end{array}$ & $\begin{array}{l}\text { Jaffe and others, } \\
2006\end{array}$ \\
\hline $\begin{array}{l}\text { Kuala Meurisi, } \\
\text { Sumatra, Indonesia }\end{array}$ & 4.617 & 95.628 & Indian Ocean & $\begin{array}{l}\text { December } \\
26,2004\end{array}$ & $\begin{array}{l}\text { Jaffe and others, } \\
2006\end{array}$ \\
\hline $\begin{array}{l}\text { Kuala Meurisi, } \\
\text { Sumatra, Indonesia }\end{array}$ & 4.617 & 95.629 & Indian Ocean & $\begin{array}{l}\text { December } \\
26,2004 \\
\end{array}$ & $\begin{array}{l}\text { Jaffe and others, } \\
2006\end{array}$ \\
\hline $\begin{array}{l}\text { Kuala Meurisi, } \\
\text { Sumatra, Indonesia }\end{array}$ & 4.618 & 95.629 & Indian Ocean & $\begin{array}{l}\text { December } \\
26,2004\end{array}$ & $\begin{array}{l}\text { Jaffe and others, } \\
2006\end{array}$ \\
\hline $\begin{array}{l}\text { Kuala Meurisi, } \\
\text { Sumatra, Indonesia }\end{array}$ & 4.619 & 95.630 & Indian Ocean & $\begin{array}{l}\text { December } \\
26,2004\end{array}$ & $\begin{array}{l}\text { Jaffe and others, } \\
2006\end{array}$ \\
\hline $\begin{array}{l}\text { Kuala Meurisi, } \\
\text { Sumatra, Indonesia }\end{array}$ & 4.619 & 95.630 & Indian Ocean & $\begin{array}{l}\text { December } \\
26,2004\end{array}$ & $\begin{array}{l}\text { Jaffe and others, } \\
2006\end{array}$ \\
\hline $\begin{array}{l}\text { Kuala Meurisi, } \\
\text { Sumatra, Indonesia }\end{array}$ & 4.620 & 95.631 & Indian Ocean & $\begin{array}{l}\text { December } \\
26,2004\end{array}$ & $\begin{array}{l}\text { Jaffe and others, } \\
2006\end{array}$ \\
\hline $\begin{array}{l}\text { Langi Island, Simelue } \\
\text { Island, Sumatra, } \\
\text { Indonesia }\end{array}$ & 2.830 & 95.766 & Indian Ocean & $\begin{array}{l}\text { December } \\
26,2004\end{array}$ & $\begin{array}{l}\text { Jaffe and others, } \\
2006\end{array}$ \\
\hline $\begin{array}{l}\text { Langi Island, Simelue } \\
\text { Island, Sumatra, } \\
\text { Indonesia }\end{array}$ & 2.830 & 95.767 & Indian Ocean & $\begin{array}{l}\text { December } \\
26,2004\end{array}$ & $\begin{array}{l}\text { Jaffe and others, } \\
2006\end{array}$ \\
\hline $\begin{array}{l}\text { Langi Island, Simelue } \\
\text { Island, Sumatra, } \\
\text { Indonesia }\end{array}$ & 2.831 & 95.767 & Indian Ocean & $\begin{array}{l}\text { December } \\
26,2004\end{array}$ & $\begin{array}{l}\text { Jaffe and others, } \\
2006\end{array}$ \\
\hline $\begin{array}{l}\text { Langi Island, Simelue } \\
\text { Island, Sumatra, } \\
\text { Indonesia }\end{array}$ & 2.831 & 95.768 & Indian Ocean & $\begin{array}{l}\text { December } \\
26,2004\end{array}$ & $\begin{array}{l}\text { Jaffe and others, } \\
2006\end{array}$ \\
\hline
\end{tabular}




\begin{tabular}{|c|c|c|c|c|c|}
\hline Site & $\begin{array}{l}\text { Latitude } \\
\text { (decimal } \\
\text { degrees) }\end{array}$ & $\begin{array}{l}\text { Longitude } \\
\text { (decimal } \\
\text { degrees) }\end{array}$ & $\begin{array}{c}\text { Name/designation of } \\
\text { tsunami }\end{array}$ & $\begin{array}{l}\text { Date of } \\
\text { tsunami }\end{array}$ & Reference \\
\hline $\begin{array}{l}\text { Langi, Simelue Island, } \\
\text { Sumatra, Indonesia }\end{array}$ & 2.829 & 95.747 & Indian Ocean & $\begin{array}{l}\text { December } \\
26,2004\end{array}$ & $\begin{array}{l}\text { Jaffe and others, } \\
2006\end{array}$ \\
\hline $\begin{array}{l}\text { Langi, Simelue Island, } \\
\text { Sumatra, Indonesia }\end{array}$ & 2.828 & 95.747 & Indian Ocean & $\begin{array}{l}\text { December } \\
26,2004\end{array}$ & $\begin{array}{l}\text { Jaffe and others, } \\
2006\end{array}$ \\
\hline $\begin{array}{l}\text { Langi, Simelue Island, } \\
\text { Sumatra, Indonesia }\end{array}$ & 2.824 & 95.757 & Indian Ocean & $\begin{array}{l}\text { December } \\
26,2004\end{array}$ & $\begin{array}{l}\text { Jaffe and others, } \\
2006\end{array}$ \\
\hline $\begin{array}{l}\text { Langi, Simelue Island, } \\
\text { Sumatra, Indonesia }\end{array}$ & 2.824 & 95.757 & Indian Ocean & $\begin{array}{l}\text { December } \\
26,2004\end{array}$ & $\begin{array}{l}\text { Jaffe and others, } \\
2006\end{array}$ \\
\hline $\begin{array}{l}\text { Langi, Simelue Island, } \\
\text { Sumatra, Indonesia }\end{array}$ & 2.824 & 95.756 & Indian Ocean & $\begin{array}{l}\text { December } \\
26,2004\end{array}$ & $\begin{array}{l}\text { Jaffe and others, } \\
2006\end{array}$ \\
\hline $\begin{array}{l}\text { Langi, Simelue Island, } \\
\text { Sumatra, Indonesia }\end{array}$ & 2.824 & 95.756 & Indian Ocean & $\begin{array}{l}\text { December } \\
26,2004\end{array}$ & $\begin{array}{l}\text { Jaffe and others, } \\
2006\end{array}$ \\
\hline $\begin{array}{l}\text { Langi, Simelue Island, } \\
\text { Sumatra, Indonesia }\end{array}$ & 2.823 & 95.759 & Indian Ocean & $\begin{array}{l}\text { December } \\
26,2004\end{array}$ & $\begin{array}{l}\text { Jaffe and others, } \\
2006\end{array}$ \\
\hline $\begin{array}{l}\text { Langi, Simelue Island, } \\
\text { Sumatra, Indonesia }\end{array}$ & 2.822 & 95.759 & Indian Ocean & $\begin{array}{l}\text { December } \\
26,2004 \\
\end{array}$ & $\begin{array}{l}\text { Jaffe and others, } \\
2006\end{array}$ \\
\hline $\begin{array}{l}\text { Langi, Simelue Island, } \\
\text { Sumatra, Indonesia }\end{array}$ & 2.822 & 95.759 & Indian Ocean & $\begin{array}{l}\text { December } \\
26,2004\end{array}$ & $\begin{array}{l}\text { Jaffe and others, } \\
2006\end{array}$ \\
\hline $\begin{array}{l}\text { Busung, Simelue } \\
\text { Island, Sumatra, } \\
\text { Indonesia }\end{array}$ & 2.388 & 96.337 & Indian Ocean & $\begin{array}{l}\text { December } \\
26,2004\end{array}$ & $\begin{array}{l}\text { Jaffe and others, } \\
2006\end{array}$ \\
\hline $\begin{array}{l}\text { Busung, Simelue } \\
\text { Island, Sumatra, } \\
\text { Indonesia }\end{array}$ & 2.385 & 96.336 & Indian Ocean & $\begin{array}{l}\text { December } \\
26,2004\end{array}$ & $\begin{array}{l}\text { Jaffe and others, } \\
2006\end{array}$ \\
\hline $\begin{array}{l}\text { Alus Alus, Simelue } \\
\text { Island, Sumatra, } \\
\text { Indonesia }\end{array}$ & 2.349 & 96.376 & Indian Ocean & $\begin{array}{l}\text { December } \\
26,2004\end{array}$ & $\begin{array}{l}\text { Jaffe and others, } \\
2006\end{array}$ \\
\hline $\begin{array}{l}\text { Langi, Simelue Island, } \\
\text { Sumatra, Indonesia }\end{array}$ & 2.861 & 95.766 & Indian Ocean & $\begin{array}{l}\text { December } \\
26,2004\end{array}$ & $\begin{array}{l}\text { Razzhigaeva and } \\
\text { others, } 2006\end{array}$ \\
\hline $\begin{array}{l}\text { Pulau Pangang Island, } \\
\text { Simelue Island, } \\
\text { Sumatra, Indonesia }\end{array}$ & 2.835 & 95.766 & Indian Ocean & $\begin{array}{l}\text { December } \\
26,2004\end{array}$ & $\begin{array}{l}\text { Razzhigaeva and } \\
\text { others, } 2006\end{array}$ \\
\hline $\begin{array}{l}\text { Lhok Pauh, Simelue } \\
\text { Island, Sumatra, } \\
\text { Indonesia }\end{array}$ & 2.861 & 95.766 & Indian Ocean & $\begin{array}{l}\text { December } \\
26,2004\end{array}$ & $\begin{array}{l}\text { Razzhigaeva and } \\
\text { others, } 2006\end{array}$ \\
\hline $\begin{array}{l}\text { Sanggiran, Simelue } \\
\text { Island, Sumatra, } \\
\text { Indonesia }\end{array}$ & 2.903 & 95.882 & Indian Ocean & $\begin{array}{l}\text { December } \\
26,2004\end{array}$ & $\begin{array}{l}\text { Razzhigaeva and } \\
\text { others, } 2006\end{array}$ \\
\hline $\begin{array}{l}\text { Buturagi, Simelue } \\
\text { Island, Sumatra, } \\
\text { Indonesia }\end{array}$ & 2.830 & 95.927 & Indian Ocean & $\begin{array}{l}\text { December } \\
26,2004\end{array}$ & $\begin{array}{l}\text { Razzhigaeva and } \\
\text { others, } 2006\end{array}$ \\
\hline $\begin{array}{l}\text { Sibao, Simelue Island, } \\
\text { Sumatra, Indonesia }\end{array}$ & 2.558 & 96.304 & Indian Ocean & $\begin{array}{l}\text { December } \\
26,2004\end{array}$ & $\begin{array}{l}\text { Razzhigaeva and } \\
\text { others, } 2006\end{array}$ \\
\hline $\begin{array}{l}\text { Lataling, Simelue } \\
\text { Island, Sumatra, } \\
\text { Indonesia }\end{array}$ & 2.467 & 96.455 & Indian Ocean & $\begin{array}{l}\text { December } \\
26,2004\end{array}$ & $\begin{array}{l}\text { Razzhigaeva and } \\
\text { others, } 2006\end{array}$ \\
\hline $\begin{array}{l}\text { Gudang, Simelue } \\
\text { Island, Sumatra, } \\
\text { Indonesia }\end{array}$ & 2.412 & 96.486 & Indian Ocean & $\begin{array}{l}\text { December } \\
26,2004\end{array}$ & $\begin{array}{l}\text { Razzhigaeva and } \\
\text { others, } 2006\end{array}$ \\
\hline $\begin{array}{l}\text { Lantic, Simelue Island, } \\
\text { Sumatra, Indonesia }\end{array}$ & 2.433 & 96.261 & Indian Ocean & $\begin{array}{l}\text { December } \\
26,2004\end{array}$ & $\begin{array}{l}\text { Razzhigaeva and } \\
\text { others, } 2006\end{array}$ \\
\hline
\end{tabular}




\begin{tabular}{|c|c|c|c|c|c|}
\hline Site & $\begin{array}{l}\text { Latitude } \\
\text { (decimal } \\
\text { degrees) }\end{array}$ & $\begin{array}{l}\text { Longitude } \\
\text { (decimal } \\
\text { degrees) }\end{array}$ & $\begin{array}{c}\text { Name/designation of } \\
\text { tsunami }\end{array}$ & $\begin{array}{l}\text { Date of } \\
\text { tsunami }\end{array}$ & Reference \\
\hline $\begin{array}{l}\text { Salur, Simelue Island, } \\
\text { Sumatra, Indonesia }\end{array}$ & 2.442 & 96.243 & Indian Ocean & $\begin{array}{l}\text { December } \\
26,2004\end{array}$ & $\begin{array}{l}\text { Razzhigaeva and } \\
\text { others, } 2006\end{array}$ \\
\hline $\begin{array}{l}\text { Busung, Simelue } \\
\text { Island, Sumatra, } \\
\text { Indonesia }\end{array}$ & 2.393 & 96.337 & Indian Ocean & $\begin{array}{l}\text { December } \\
26,2004\end{array}$ & $\begin{array}{l}\text { Razzhigaeva and } \\
\text { others, } 2006\end{array}$ \\
\hline $\begin{array}{l}\text { Sineubuk, Simelue } \\
\text { Island, Sumatra, } \\
\text { Indonesia }\end{array}$ & 2.341 & 96.356 & Indian Ocean & $\begin{array}{l}\text { December } \\
26,2004\end{array}$ & $\begin{array}{l}\text { Razzhigaeva and } \\
\text { others, } 2006\end{array}$ \\
\hline $\begin{array}{l}\text { Pantai Cermin, } \\
\text { Simelue Island, } \\
\text { Sumatra, Indonesia }\end{array}$ & 3.651 & 98.908 & Indian Ocean & $\begin{array}{l}\text { December } \\
26,2004\end{array}$ & $\begin{array}{l}\text { Razzhigaeva and } \\
\text { others, } 2006\end{array}$ \\
\hline $\begin{array}{l}\text { Kuala Lama, Simelue } \\
\text { Island, Sumatra, } \\
\text { Indonesia }\end{array}$ & 3.631 & 99.020 & Indian Ocean & $\begin{array}{l}\text { December } \\
26,2004\end{array}$ & $\begin{array}{l}\text { Razzhigaeva and } \\
\text { others, } 2006\end{array}$ \\
\hline $\begin{array}{l}\text { Kuala Lama, Simelue } \\
\text { Island, Sumatra, } \\
\text { Indonesia }\end{array}$ & 3.631 & 99.020 & Indian Ocean & $\begin{array}{l}\text { December } \\
26,2004\end{array}$ & $\begin{array}{l}\text { Razzhigaeva and } \\
\text { others, } 2006\end{array}$ \\
\hline Nam Khem,Thailand & 8.858 & 98.266 & Indian Ocean & $\begin{array}{l}\text { December } \\
26,2004\end{array}$ & $\begin{array}{l}\text { Szczucinski and } \\
\text { others, } 2005\end{array}$ \\
\hline Patong, Thailand & 7.882 & 98.288 & Indian Ocean & $\begin{array}{l}\text { December } \\
26,2004\end{array}$ & $\begin{array}{l}\text { Szczucinski and } \\
\text { others, } 2005\end{array}$ \\
\hline Patong Bay, Thailand & 7.885 & 98.274 & Indian Ocean & $\begin{array}{l}\text { December } \\
26,2004\end{array}$ & $\begin{array}{l}\text { Szczucinski and } \\
\text { others, } 2005\end{array}$ \\
\hline Bang Mor, Thailand & 8.833 & 98.269 & Indian Ocean & $\begin{array}{l}\text { December } \\
26,2004\end{array}$ & $\begin{array}{l}\text { Szczucinski and } \\
\text { others, } 2005\end{array}$ \\
\hline La Quinta, Peru & -16.648 & -72.723 & Southern Peru & $\begin{array}{l}\text { June 23, } \\
2001\end{array}$ & $\begin{array}{l}\text { Morton and others, } \\
2007\end{array}$ \\
\hline Playa Jahuay, Peru & -16.548 & -72.873 & Southern Peru & $\begin{array}{l}\text { June 23, } \\
2001\end{array}$ & $\begin{array}{l}\text { Morton and others, } \\
2007\end{array}$ \\
\hline Amecosupe, Peru & -16.658 & -72.663 & Southern Peru & $\begin{array}{l}\text { June 23, } \\
2001\end{array}$ & $\begin{array}{l}\text { Morton and others, } \\
2007\end{array}$ \\
\hline La Quinta, Peru & -16.648 & -72.723 & Southern Peru & $\begin{array}{l}\text { June 23, } \\
2001\end{array}$ & $\begin{array}{l}\text { Jaffe and others, } \\
2003\end{array}$ \\
\hline Playa Jahuay, Peru & -16.548 & -72.873 & Southern Peru & $\begin{array}{l}\text { June 23, } \\
2001\end{array}$ & $\begin{array}{l}\text { Jaffe and others, } \\
2003\end{array}$ \\
\hline Amecosupe, Peru & -16.658 & -72.663 & Southern Peru & $\begin{array}{l}\text { June 23, } \\
2001\end{array}$ & $\begin{array}{l}\text { Jaffe and others, } \\
2003\end{array}$ \\
\hline $\begin{array}{l}\text { Waipo, Papua New } \\
\text { Guinea }\end{array}$ & -3.121 & 142.288 & Papua New Guinea & $\begin{array}{l}\text { July 17, } \\
1998\end{array}$ & $\begin{array}{l}\text { Gelfenbaum and } \\
\text { Jaffe, } 2003\end{array}$ \\
\hline $\begin{array}{l}\text { Waipo, Papua New } \\
\text { Guinea }\end{array}$ & -3.121 & 142.288 & Papua New Guinea & $\begin{array}{l}\text { July } 17, \\
1998\end{array}$ & $\begin{array}{l}\text { Morton and others, } \\
2007\end{array}$ \\
\hline $\begin{array}{l}\text { Arop, Papua New } \\
\text { Guinea }\end{array}$ & -3.063 & 142.139 & Papua New Guinea & $\begin{array}{l}\text { July } 17, \\
1998\end{array}$ & $\begin{array}{l}\text { Morton and others, } \\
2007\end{array}$ \\
\hline $\begin{array}{l}\text { Otto, Papua New } \\
\text { Guinea }\end{array}$ & -3.022 & 142.084 & Papua New Guinea & $\begin{array}{l}\text { July 17, } \\
1998\end{array}$ & $\begin{array}{l}\text { Morton and others, } \\
2007\end{array}$ \\
\hline $\begin{array}{l}\text { Sissano, Papua New } \\
\text { Guinea }\end{array}$ & -2.999 & 142.054 & Papua New Guinea & $\begin{array}{l}\text { July 17, } \\
1998\end{array}$ & $\begin{array}{l}\text { Morton and others, } \\
2007\end{array}$ \\
\hline $\begin{array}{l}\text { Otto, Papua New } \\
\text { Guinea }\end{array}$ & -3.022 & 142.084 & Papua New Guinea & $\begin{array}{l}\text { July 17, } \\
1998\end{array}$ & $\begin{array}{l}\text { Gelfenbaum and } \\
\text { Jaffe, } 2003\end{array}$ \\
\hline $\begin{array}{l}\text { Sissano, Papua New } \\
\text { Guinea }\end{array}$ & -2.999 & 142.054 & Papua New Guinea & $\begin{array}{l}\text { July 17, } \\
1998\end{array}$ & $\begin{array}{l}\text { Gelfenbaum and } \\
\text { Jaffe, } 2003\end{array}$ \\
\hline
\end{tabular}




\begin{tabular}{|c|c|c|c|c|c|}
\hline Site & $\begin{array}{l}\text { Latitude } \\
\text { (decimal } \\
\text { degrees) }\end{array}$ & $\begin{array}{c}\text { Longitude } \\
\text { (decimal } \\
\text { degrees) }\end{array}$ & $\begin{array}{c}\text { Name/designation of } \\
\text { tsunami }\end{array}$ & $\begin{array}{l}\text { Date of } \\
\text { tsunami }\end{array}$ & Reference \\
\hline $\begin{array}{l}\text { Arop, Papua New } \\
\text { Guinea }\end{array}$ & -3.063 & 142.139 & Papua New Guinea & $\begin{array}{l}\text { July } 17, \\
1998\end{array}$ & $\begin{array}{l}\text { Gelfenbaum and } \\
\text { Jaffe, } 2003\end{array}$ \\
\hline Puerto Santo, Peru & -8.991 & -78.652 & $\begin{array}{l}\text { Chimbote, Northern } \\
\text { Peru }\end{array}$ & $\begin{array}{l}\text { February 21, } \\
1996\end{array}$ & $\begin{array}{l}\text { Bourgeois and others, } \\
1999\end{array}$ \\
\hline $\begin{array}{l}\text { North of Rio Santa } \\
\text { River mouth, Peru }\end{array}$ & -8.963 & -78.643 & $\begin{array}{l}\text { Chimbote, Northern } \\
\text { Peru }\end{array}$ & $\begin{array}{l}\text { February 21, } \\
1996\end{array}$ & $\begin{array}{l}\text { Bourgeois and others, } \\
1999\end{array}$ \\
\hline $\begin{array}{l}\text { Rajagwesi, Java, } \\
\text { Indonesia }\end{array}$ & -8.571 & 113.916 & Java & June 3, 1994 & $\begin{array}{l}\text { Dawson and others, } \\
1996\end{array}$ \\
\hline $\begin{array}{l}\text { Usubetsu River, } \\
\text { Hokkaido, Japan }\end{array}$ & 42.218 & 139.867 & Hokkaido-nansei-oki & $\begin{array}{l}\text { July 12, } \\
1993\end{array}$ & $\begin{array}{l}\text { Nanayama and } \\
\text { Shigeno, } 2006\end{array}$ \\
\hline $\begin{array}{l}\text { Usubetsu River, } \\
\text { Hokkaido, Japan }\end{array}$ & 42.218 & 139.867 & Hokkaido-nansei-oki & $\begin{array}{l}\text { July 12, } \\
1993\end{array}$ & $\begin{array}{l}\text { Nanayama and } \\
\text { Shigeno, } 2006\end{array}$ \\
\hline $\begin{array}{l}\text { Hirahama, Hokkaido, } \\
\text { Japan }\end{array}$ & 42.210 & 139.882 & Hokkaido-nansei-oki & $\begin{array}{l}\text { July 12, } \\
1993\end{array}$ & $\begin{array}{l}\text { Nanayama and } \\
\text { others, } 2000\end{array}$ \\
\hline $\begin{array}{l}\text { Honme, Hokkaido, } \\
\text { Japan }\end{array}$ & 42.747 & 140.138 & Hokkaido-nansei-oki & $\begin{array}{l}\text { July 12, } \\
1993\end{array}$ & $\begin{array}{l}\text { Nishimura and } \\
\text { Miyaji, } 1995\end{array}$ \\
\hline $\begin{array}{l}\text { Enoshima, Hokkaido, } \\
\text { Japan }\end{array}$ & 42.681 & 140.010 & Hokkaido-nansei-oki & $\begin{array}{l}\text { July 12, } \\
1993\end{array}$ & $\begin{array}{l}\text { Nishimura and } \\
\text { Miyaji, } 1995\end{array}$ \\
\hline $\begin{array}{l}\text { Enoshima, Hokkaido, } \\
\text { Japan }\end{array}$ & 42.681 & 140.010 & Hokkaido-nansei-oki & $\begin{array}{l}\text { July 12, } \\
1993\end{array}$ & $\begin{array}{l}\text { Nishimura and } \\
\text { Miyaji, } 1995\end{array}$ \\
\hline $\begin{array}{l}\text { Taisei, Hokkaido, } \\
\text { Japan }\end{array}$ & 42.218 & 139.870 & Hokkaido-nansei-oki & $\begin{array}{l}\text { July 12, } \\
1993\end{array}$ & $\begin{array}{l}\text { Nishimura and } \\
\text { Miyaji, } 1995\end{array}$ \\
\hline $\begin{array}{l}\text { Setana, Okushiri Island } \\
\text { and Oshima peninsula, } \\
\text { Hokkaido, Japan }\end{array}$ & 42.446 & 139.852 & Hokkaido-nansei-oki & $\begin{array}{l}\text { July 12, } \\
1993\end{array}$ & Sato and others, 1995 \\
\hline $\begin{array}{l}\text { East Coast Okushiri } \\
\text { Island, Hokkaido, } \\
\text { Japan }\end{array}$ & 42.169 & 139.521 & Hokkaido-nansei-oki & $\begin{array}{l}\text { July 12, } \\
1993\end{array}$ & Sato and others, 1995 \\
\hline $\begin{array}{l}\text { Kamuiwaki, } \\
\text { Hokkaido, Japan }\end{array}$ & 41.865 & 140.121 & Hokkaido-nansei-oki & $\begin{array}{l}\text { July 12, } \\
1993\end{array}$ & Sato and others, 1995 \\
\hline $\begin{array}{l}\text { Monai, Hokkaido, } \\
\text { Japan }\end{array}$ & 42.105 & 139.425 & Hokkaido-nansei-oki & $\begin{array}{l}\text { July 12, } \\
1993\end{array}$ & Sato and others, 1995 \\
\hline $\begin{array}{l}\text { south of Monai, } \\
\text { Hokkaido, Japan }\end{array}$ & 42.105 & 139.425 & Hokkaido-nansei-oki & $\begin{array}{l}\text { July 12, } \\
1993\end{array}$ & Sato and others, 1995 \\
\hline $\begin{array}{l}\text { Hamatsumae, } \\
\text { Hokkaido, Japan }\end{array}$ & 42.072 & 139.474 & Hokkaido-nansei-oki & $\begin{array}{l}\text { July 12, } \\
1993\end{array}$ & Sato and others, 1995 \\
\hline $\begin{array}{l}\text { Inaho, Hokkaido, } \\
\text { Japan }\end{array}$ & 42.241 & 139.552 & Hokkaido-nansei-oki & $\begin{array}{l}\text { July 12, } \\
1993\end{array}$ & Sato and others, 1995 \\
\hline $\begin{array}{l}\text { Aonae, Hokkaido, } \\
\text { Japan }\end{array}$ & 42.069 & 139.456 & Hokkaido-nansei-oki & $\begin{array}{l}\text { July 12, } \\
1993\end{array}$ & Sato and others, 1995 \\
\hline $\begin{array}{l}\text { Aonae, Hokkaido, } \\
\text { Japan }\end{array}$ & 42.069 & 139.456 & Hokkaido-nansei-oki & $\begin{array}{l}\text { July 12, } \\
1993 \\
\end{array}$ & Sato and others, 1995 \\
\hline $\begin{array}{l}\text { Babi Island, } 5 \mathrm{~km} \text { off } \\
\text { northern coast of } \\
\text { Flores Island, } \\
\text { Indonesia }\end{array}$ & 2.072 & 96.625 & Flores & $\begin{array}{l}\text { December } \\
12,1992\end{array}$ & $\begin{array}{l}\text { Minoura and others, } \\
1997\end{array}$ \\
\hline $\begin{array}{l}\text { Riangkrok, Flores } \\
\text { Island, Indonesia }\end{array}$ & -8.171 & 122.768 & Flores & $\begin{array}{l}\text { December } \\
12,1992\end{array}$ & Shi and others, 1995 \\
\hline $\begin{array}{l}\text { Nebe, Flores Island, } \\
\text { Indonesia }\end{array}$ & -8.459 & 122.528 & Flores & $\begin{array}{l}\text { December } \\
12,1992\end{array}$ & Shi and others, 1995 \\
\hline $\begin{array}{l}\text { Lato, Flores Island, } \\
\text { Indonesia }\end{array}$ & -8.355 & 122.749 & Flores & $\begin{array}{l}\text { December } \\
12,1992\end{array}$ & Shi and others, 1995 \\
\hline
\end{tabular}




\begin{tabular}{|l|c|c|l|l|l|}
\hline \multicolumn{1}{|c|}{ Site } & $\begin{array}{c}\text { Latitude } \\
\text { (decimal } \\
\text { degrees) }\end{array}$ & $\begin{array}{c}\text { Longitude } \\
(\text { decimal } \\
\text { degrees })\end{array}$ & $\begin{array}{l}\text { Name/designation of } \\
\text { tsunami }\end{array}$ & \multicolumn{1}{|c|}{$\begin{array}{l}\text { Date of } \\
\text { tsunami }\end{array}$} & \multicolumn{1}{|c|}{ Reference } \\
\hline $\begin{array}{l}\text { Playa de Popoyo, Las } \\
\text { Salinas }\end{array}$ & 11.477 & -86.139 & Nicaragua & $\begin{array}{l}\text { September } \\
2,1992\end{array}$ & $\begin{array}{l}\text { Higman and } \\
\text { Bourgeois, 2008 }\end{array}$ \\
\hline Hawaii & & & Chile & $\begin{array}{l}\text { May 22, } \\
1960\end{array}$ & $\begin{array}{l}\text { Eaton and others, } \\
1961\end{array}$ \\
\hline Chile & & & Chile & $\begin{array}{l}\text { May 22, } \\
1960\end{array}$ & $\begin{array}{l}\text { Wright and Mella, } \\
1963\end{array}$ \\
\hline Haena, Kauai, Hawaii & 22.219 & -159.565 & Aleutian Islands & $\begin{array}{l}\text { April 1, } \\
1946\end{array}$ & $\begin{array}{l}\text { Shepard and others, } \\
1950\end{array}$ \\
\hline
\end{tabular}

